\title{
Giving an Identity: Coordinates of Invention. Heresy and Dissidence Among Non-Philosophers ${ }^{1}$ \\ | Narciso Aksayam
}

\section{Bionote}

Born in 1975, physiotherapist, epistemology teacher at Institut de formation de massokinésithérapie (Reims, France), Narciso Aksayam conducts research about how to teach and how to learn immanence in an embodied perspective of questioning (both at Catholic University of Louvain, Belgium, and Rouen, France). As an editor and as a journalist he has conducted many interviews with François Laruelle and Serge Valdinoci, and he has published several archives of non-philosophy and unpublished papers and films of Gilles Grelet. As a translator, he was invited by Katerina Kolozova to accompany François Laruelle and Anne-Françoise Schmid during the summer school New Forms of Realism in Contemporary Philosophy in Ohrid, Macedonia, 2015. As a literary critic, he has published several articles and reviews about contemporary French poetry (in Cahier critique de Poésie, centre international de poésie Marseille) and was invited in 2017 at the Poetry Market of Paris to present recent developments in the poetical fields of embodiment and hypnosis.

Catholic University of Louvain

n.aksayam@gmail.com

\section{Abstract}

Not known enough for his former publications in philosophy, François Laruelle's at

\footnotetext{
1 Identities would like to thank Taylor Adkins, who generously edited this text. - Ed.
}

tempt to institute a democratic field for all hermeneutic content and every philosophical knowledge is not that easy to re-enact starting from the Nietzschean and Levinassian apparatus of his early thought, and considering the refusal of reciprocity that is correlated with his theory of Unilaterality.

This difficulty also manifests in the résumé of his philosophical career. Though presented for a long time as solitary, Laruelle recently acknowledged that his work had been built within the dynamic of colleagues and disciples as well. From there, an insight on the intersubjective past of non-philosophy will unfold the coextensive network of affects that are part of its construction as a matrix of Democracy. And since Heresy is one of the major figures of Laruelle's thought, it is interesting to pay attention to how dissidences have been dealt with in his own discourse and posture while non-philosophy was emerging as an intersubjective assemblage.

Two historical characters will be considered: Serge Valdinoci, an early collaborator in the 1980s, who built a specific method of immanence, europanalysis, and who distanced himself from non-philosophy at the turning of Philosophy III; and Gilles Grelet, a prominent disciple in the 1990s, who co-founded Organisation Non-Philosophique Internationale (ONPhI) 
with Ray Brassier, and who played such a major role in non-philosophy that it drove Laruelle to write Struggle and Utopia at the End Times of Philosophy. ${ }^{2}$

Keywords: democracy, europanalysis, Serge Valdinoci, heresy, Gilles Grelet, intersubjectivity, non-philosophy, François Laruelle

\section{Introduction}

There are many fictions surrounding nonphilosophy. We all know that this is a necessary part of the results of Laruelle's works. one explicit goal that can summarize both the way (the method) and the practice (the deed) of non-standard thought is to set Philosophy free by resorting to philo-fictions or by means of its metamorphosis/transvaluation into Fiction. And, as far as we can observe, this leads philosophical thought to both invention and harmlessness and also leads it to leave both the powers and shackles of Sufficiency, i.e., to recognize and to renew the use of Decision within Thought through a process of weakening Philosophy or, as Laruelle describes it, a proposal of degrowth. ${ }^{3}$

\footnotetext{
2 François Laruelle, Struggle and Utopia at the End Times of Philosophy, trans. by Drew Burk and Anthony Paul Smith (Minneapolis, Minnesota: Univocal, 2012).

3 Narciso Aksayam (Ed.), \#TRANSISTOR [DVD-ROM] (Plancyl'Abbaye: INgens, 2012). All translations from the French, unless otherwise indicated, are mine, and all French references are taken from their original editions
}

Nonetheless, this freedom of invention, which can also be described - we now know this too well - as a Redemption for the Hell of the World that we live in, has a price: the price that has to be paid to Rigor. And when we speak of an axiomatic method, Rigor is the non-thetic name of Truth, although we might no longer be able to bear such a theoretical burden that currently comes with this name. Assertions about non-philosophy are not assertions about the World, i.e., about Philosophy, and are even less assertions from Philosophy - at the very least we should have to be careful, methodologically careful, about them for them not to be so. But one trap that we always fall into within the non-philosophical matrix is that we have to deal with descriptions that are two-sided and unsymmetrical. This is the unbalanced price of the rigorous Unilaterality that we accept, that we greet as an eminent process of the Real or as an emanating effect that circumscribes it from the ground of descriptions.

\section{Democracy at the Expense of Reciprocity}

Most of us - especially since 1996's Principles of Non-Philosophy ${ }^{4}$ which, together with Théorie des Étrangers. Science des hom-

with paginations. Some translations from the French have been consulted with and edited by Taylor Adkins.

4 François Laruelle, Principles of Non-Philosophy, trans. by Nicola Rubczak and Anthony Paul Smith (London: Bloomsbury, 2013). 
mes, démocratie, non-psychanalyse [Theory of Strangers: Science of Humans, Democracy, NonPsychoanalysis], ${ }^{5}$ opened the third age of the philosophies that Laruelle has used to distinguish within his own work ${ }^{6}$ - have welcomed and have even acclaimed the statement that nonstandard thought is the long-awaited (messianic?) framework for introducing Democracy among thoughts. And that is precisely the meaning that we witness in the title of the deservingly well-known book by John ó Maoilearca of 2015: All Thoughts are Equal. ${ }^{7}$ Yet, regarding the rigorous mechanisms that lead to this result and keeping in sight the complex two-sided descriptions that non-philosophical propositions always involve (or import into their utterance), we have to remember that Laruelle's work, from the very beginning of his writings, is more about sovereignty and about releasing a radical affect of subordination within experience than it is about Democracy or equality of status in Thought. We cannot ignore that Unilaterality is about undisputable hierarchy or act as if it is not.

This is indisputable at first, because Unilaterality is far from the reach of any

\footnotetext{
5 François Laruelle, Théorie des Étrangers. Science des hommes, démocratie, non-psychanalyse (Paris: Kimé, 1995). 6 Regarding Laruelle's own periodization of his work (Philosophy I to V), see Laruelle, Principles, 307-8. 7 John Ó Maoilearca, All Thoughts Are Equal: Laruelle and Nonhuman Philosophy (Minneapolis, Minnesota: University of Minnesota Press, 2015).
}

contortion of Logos: the One forbids Agora and incapacitates its claims to rule any aspect of the Real. And it is also impregnable because it puts an absolute one-way direction into causality (but maybe rather "invents" than "puts," if we quibble over vocabulary), and it is one-way to such an extent that we have become familiar with the name "The Last Instance," which determines its effects without even being known as a cause by whatever undergoes its determination. Here is the strict formulation of what Laruelle from early on used to call, in an obviously Deleuzian reference and continuity, the process of machinic syntaxes, which were described according to the causality originating in the other or in Difference: $X$ distinguishes itself from $Y$ which does not distinguish itself from it. 8

8 This axiom is initially taken from François Laruelle, Le déclin de l'écriture. Suivi d'entretiens avec JeanLuc Nancy, Sarah Koffman, Jacques Derrida, Philippe Lacoue-Labarthe (Paris: Aubier-Flammarion, 1977), 7. But the oldest formulation of this syntactic matrix can be found in Laruelle's doctoral dissertation: "the series of emissions (noeses) only moves forward by following the traces of the other from which it distinguishes itself at the same time as it is identical to it, but more powerful, more sovereign, never separated from what it produces." François Laruelle, Économie générale des effets d'être, tome 1 (thèse de doctorat, Paris: Université Paris Nanterre, 1974), 183. We can encounter the same syntax published for the first time in Machines textuelles [Textual Machines] and applied to define the term machinic as it specifies a functioning of drives: "the effect of a drive distinguishes itself from this drive which does not distinguish itself from its effect." François Laruelle, Machines textuelles. Déconstruction et 
Due to the lack of available translations, most of the present-day readers of Laruelle, especially in the English-speaking world, may feel the posture or this reading of non-philosophy's statements as having a little bit too much of a Nietzschean taste. After all, Laruelle's recent publications - especially since the "amplification of non-philosophy," which he has accomplished by quantum-colliding inside a generic matrix of thought - have implied a radical stepping beyond previous formulations of his work. ${ }^{9}$ But we could consider this as a second trap into which any attempt at catching up with non-philosophy's theoretical discourse has to fall, albeit a trap that is more external than the genuine two-sided complex representations we indicated above. This trap could be identified as a systematic-axiomatic illusion, the temptation to receive the internal consistency of the axiomatic apparatus, its internal structural rigor, as having no genetic or historical manifestation, i.e., the belief that the theoretical edifice as a whole is given as such immediately, and the denial that it is the result of a long lasting work: a character-

libido d'écriture (Paris: Seuil, 1976), 10. A translation of the "Introduction" by Taylor Adkins is available online at Speculative Heresy, September 1, 2013, WWw. speculativeheresy. wordpress . com/2013/09/01/translationof-f-laruelles-introduction-to-textual-machines.

9 François Laruelle, Philosophie non-standard. Générique, quantique, philo-fiction (Paris: Kimé, 2010). A

translation by Taylor Adkins and Rocco Gangle of this book is forthcoming in 2019 by Columbia University Press. istic confusion between the experience and the production of its description, which brings us to the naïve belief in the sheer elimination of one step of non-philosophy by its next step.

There is no concept more Deleuzian-Nietzschean, although it had been enveloped earlier within the Marxist name of "determination in the last instance," than the concept of unilaterality to describe the specific deconstructive causality that has motivated Laruelle since his initial publications. ${ }^{10}$ The unilateral syntax of sovereignty (already two-sided as it is implied in the Derridean protocol of supplementation) goes through the prior period of Philosophy I until it coagulates with the problematic of finitude, which culminates with the question of Power and Mastery: How to articulate a theoretical matrix that embodies its own finitude within the laws of its machinic functioning?, with the initial Heideggerian questionings that launched Laruelle's research: What is the principle of production and reproduction of

\footnotetext{
10 The concept of unilaterality is hard to identify quickly in Nietzsche's work, because Nietzsche is quite obsessive about causality: just having a look at Friedrich Nietzsche, The Gay Science: With a Prelude in Rhymes and an Appendix of Songs, trans. by Walter Kaufmann (New York: Vintage Books, 1974), § 112, 127, 217, 360, 374, illustrates this clearly enough; but a thorough reading of the first paragraph of Deleuze's Chapter I: "Difference in Itself," Difference and Repetition, trans. by Paul Patton (New York: Columbia University Press, 1994), 28-69, will convince any reader of what is taking place at this very moment in European thought.
} 
the various meanings of Being? What is the law of the authentic functioning of the effects-of-Being that combines the destruction of their metaphysical and repressive forms with the production of these effects as such $?^{11}$

Figure 1. Laruelle's

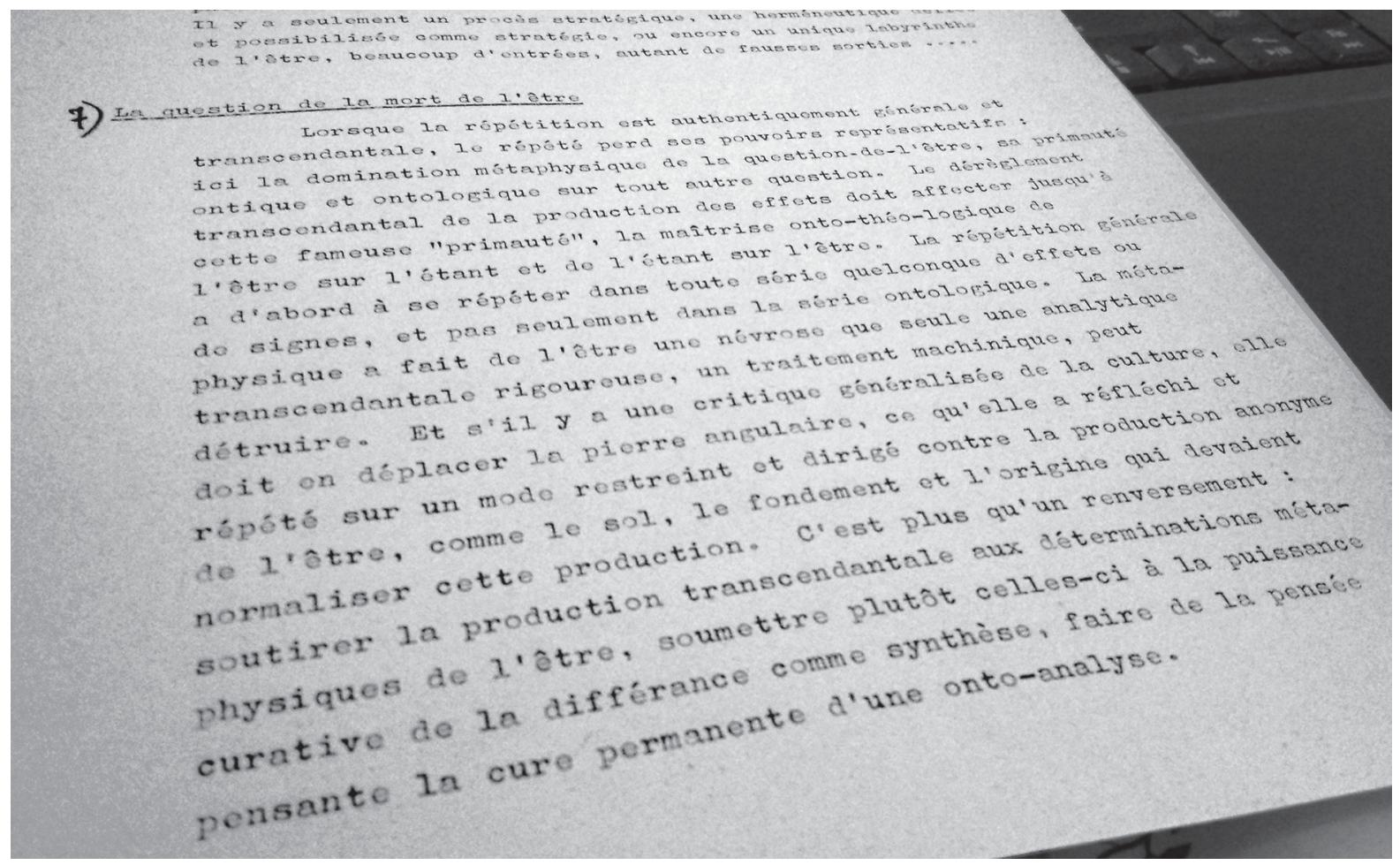
unpublished doctoral

dissertation, titled Economie générale des effets d'être (new abridged version title: Au-delà de I'Idée), presented and defended in 1974 under the supervision of Paul Ricœur (1913-2005) .

11 Laruelle, Économie, 2. From an initial formalization of the syntactic essential processes of Deconstruction through the ontological embedding of Decline (i.e., Finitude as a becoming) - Decline of Writing, and thereupon of Hermeneutics - Philosophy I can be summarized as the ornery attempt to melt the esoteric transcendental framework shaped by both Nietzschean Will to Power and Eternal Return (of the Same/as the other), with an active-affirmative interpretation of Finitude taken from Levinas' sharp demur, to Phenomenology as an ethical ascendency of powerlessness.
The turn to Philosophy II in the early 1980s coincides with the renunciation of formulating this principle of finitude from within Philosophy and with the acceptance/discovery that this finitude shall be absolutely immanent only if received from outside Philosophy and Logos. From the point of view of Philosophy, this is a turn from an internal finitude to an external finitude. But from a non-philosophical position of vision, this is a theoretical correction corresponding to a lived and contemplative affect of indifference that defines in new terms a science and its own force (of) thought: 
a Science that turns Philosophy into a mere object which can thenceforth be treated as a material and can from then on be incomparably invented.

But this affect as such is not an affect of Democracy. Since it is described as a pure affect (of) impregnable self-inherency with neither content nor predicate, it is an affect of solitude and uselessness, ${ }^{12}$ an affect of division whose cut Philosophy cannot bear, whose sovereign inertia Philosophy cannot stand, especially since Philosophy represses its transcendental need for this engine of otherness as a function in its own economy of movement and Becoming (for instance, in the case of Laruelle's Philosophy I: the question of what is the energetic libido that drives any deconstructionist at work).

There is no way that leads by means of equality to a theoretical position where solitude is freed from reciprocity. How could we establish a unilateral freedom of causality, an unreciprocal determination, by any kind of democratic interplay? Indifference is the very trait of sovereignty. To choose one's enemy without being exposed to being chosen by anything, by anyone, to be the enemy accepting the attacks that one undergoes as valuable events (there are countless metaphorical variations in

\footnotetext{
12 François Laruelle, Principes de la non-philosophie (Paris: Presses Universitaires de France, 1996), 168.
}

Nietzsche's writings about this elitist causality) is a Nietzschean luxury.

Actually, we cannot deny that non-philosophy provides equality and Democracy. But it is a very strange kind. Since it is a Democracy among Philosophies' discourses and procedures, non-philosophy is more akin to a Democracy of Subordinates, the achievement of equality among subalterns. From an aristocratic posture, in the way Deleuze could have expressed this in his anti-Hegelian Nietzsche and Philosophy, ${ }^{13}$ we could say that all slaves are equal (specifically from the master's perspectives ${ }^{14}$ ). Because, if theory manages to make Philosophies equal, this is only from a non-philosophical radical hierarchy, an affectively lived one. In that sense, we probably should not talk about equality but rather about equanimity, which is one true name of Indifference, since "being equal" in French literally means "it doesn't matter" (ça $m^{\prime}$ est égal).

Yet, since Philosophy in non-standard thought becomes both an object of interest for a new science and a raw material for experimenting invention through fictionalizing Decision (especially as an art of axiomatics), we must be more accurate in our formula. Rather than talk of slaves, the correct phrasing would be all guinea pigs are equal. They are equally

13 Gilles Deleuze, Nietzsche and Philosophy, trans. by Hugh Tomlinson (London: The Alhlone Press, 1983).

14 Deleuze, Nietzsche and Philosophy, 8-10. 
faced with a non-standard posture, whose use, since the turn to Philosophy III, of a strange unquestioned unethical metaphor to describe an effect of its immediate syntactical framework - cloning - we cannot ignore. (As a reminder, the famous sheep Dolly, now taxidermized and resting at the National Museum of Scotland, was born by way of cloning, using the process of nuclear transfer, precisely in 1996; this scientific issue was on everyone's lips when Laruelle was writing - and teaching - the Principles. ${ }^{15}$ )

In fact, and to conclude the matter, rather than all thoughts are equal, we should understand all worlds are equal because, in the frame of non-philosophy, all thoughts are not. Unless we consider the Vision-in-One not to be a thought, even though a very lonely and very hieratic one. This is a meticulous issue of definition: concerning what non-philosophy considers Thinking, concerning what borders it draws (if it does) between Thought and Experience or

\footnotetext{
15 Laruelle has never spared the funny and slightly cheesy references in his discourse. In the 1980s, it was obvious for the French ear that the acronym for NonThetic Transcendence was referring to Trinitrotoluene: T.N.T., an explosive; but nowadays T.N.T. rather indicates Digital Terrestrial Television... This is the sad becoming of humoristic otherness (though nonautopositional) lost in the coming and going waves of culture. See François Laruelle, Une biographie de l'homme ordinaire. Des Autorités et des Minorités (Paris: Aubier, 1985); English edition: François Laruelle, A Biography of ordinary Man: On Authorities and Minorities, trans. by Jessie Hock and Alex Dubilet (Cambridge: Polity, 2018).
}

lived experience (Erlebnis), concerning if it limits Thought to the mere domain of Intuition or if it confines the task of non-philosophy no longer to be Heideggerian "thinking Thought," destined to destroy the onto-theo-logical repression of Being's Sovereignty of production, the oppression of Metaphysics, which has always lived on the repression of these productive effects-of-Being, and to derive from Being a brand new jouissance. ${ }^{16}$

At least we already know that non-philosophical thought is described by Laruelle as un-reflected, non-egological, without repeating; and that it stands as a whole with the given-without-givenness: as a consequence of the fact (the lived experience) that the givenwithout-givenness shows itself rather (from) itself, and consequently through the form of the thought of which it is the cause. ${ }^{17}$ And since this thought, with neither affirmation nor negation, without any kind of position, is mere and "neutral," it clearly enjoys a different status because it invalidates all objections brought by philosophical thought. These are precisely the terms of an essential asymmetry between obviously different kinds of thought, if not different natures or essences.

The only reason why we stomach this blatant lack of Democracy in the non-standard ap-

\footnotetext{
16 Laruelle, Économie, 3.

17 Laruelle, Principes, 122.
} 
paratus, the only reason why we tolerate it and are even prone to support it, is because the undisputable hierarchy that it builds places an absolute lack of contents, a radical void of attributes and an indescribable absence of self-consistency or self-sufficiency in the position of unilateral Determination, which is a position of absolute (auto)nomy and absolute sovereignty, if not (precisely because it consists of no substance) absolute tyranny. Is this what Derrida was tempted to see as a transcendental reign of terror in Laruelle's own practice? ${ }^{18}$

Admittedly, being invisible, being intangible, being impregnable, being immaterial or unsubstantial, i.e., being radically elusive, cannot be described as an authoritarian position, or as an aggressive potential, but neither can it be denied being a radical power. This is the radical power to drive anything or anyone powerless. There are numerous mundane representations of such power or of the endeavor to somehow reach it: from the Marvel mutant character Kitty Pride to the fog-convertible Count Dracula; from the martial art of Aikido

\footnotetext{
18 François Laruelle et Jacques Derrida, "Controverse sur la possibilité d'une science de la philosophie," La décision philosophique, No. 5 (avril 1988), 62-76; English edition: François Laruelle and Jacques Derrida, "Controversy Over the Possibility of a Science of Philosophy," trans. by Ray Brassier and Robin Mackay, in The Non-Philosophy Project, ed. Gabriel Alkon and Boris Gunjevic (New York: Telos), 76-94.
}

to the unspeakable truth of Tao; from Christian negative theology to the uncategorizable and unfigurable God within Muslim traditions... In the ability not to support any predicate, i.e., in the capacity to avoid being an object in any way - even in the dual and circular contemporary mode - lies the power to thwart any intention, to defeat any law, to frustrate any knowledge, and even, in the epistemo(logical) case of nonphilosophy, to escape any intuition.

The absolute hierarchy in which such a power indulges is tolerable in a democratic apparatus (dispositif) only because of emptiness, only because of an essential disruptive opening. But on the other hand, its dense (rather than hermetic) emptiness is what provides it with its utter power. Here we begin to glimpse some of the exact syntax of its immanence. Yet we are also able to discern that this power, which deeply lies in disappointment, is radical rather than absolute, in the sense that it needs an occasion (an intention, the beginning of an attempt, the habits of a practice or the reflex of a movement) to be exerted, to affect anything or anyone. Indifference means nothing without a stimulus to experience it or to sort of trigger it: to manifest it as an effect, even when caused by foreclosure. Within these lines, we attain precisely the terms that redistribute the respective positions and functions of transcendence and immanence within the model that Philosophy III displayed in the 1990s. 
But Laruelle goes further. Not only does this Sovereignty get its power and its ultimate hierarchical position in the sequence of determinations from its absolute weakness and inconsistency, its allergy or its immunity to any predicates, any content, any objectification or any self-intuitive fold, but Laruelle also prevents it from ever being privatized or appropriated - even by science itself (as he acknowledges that Philosophy II was too close to such a risk $^{19}$ ).

As a pure dispersive efficiency, as an absolute repulsive might, as the causality of the unconditional otherness that refuses ontological determinations (of knowledge, of mastery, of Being as the ultimate frame of Phenomenology...), unilateral sovereignty has already been used and defined in prior ways as a tool of exception - in Levinas, for example, enabling Jewishness to avoid the requisition from philosophical Greekness (and here stands the messianic feature of revolutionary discontinuity, as Ernst Bloch, for example, has shown about Thomas Münzer $\left.{ }^{20}\right)$. And we could somehow describe the same uses currently around Blackness and the development of Radical Black Thought: Absolute Sovereignty is of great use or carries great positions of freedom in the formalization of a

19 Laruelle, Principes, 59.

${ }^{20}$ We sure are still waiting for a serious publication confronting Laruelle and Bloch on utopia, ethics and the futural. process of decolonization of thought and feelings. But from a non-philosophical point of appreciation, these remain local deconstructive praxes, intermediary recourses, and unrigorous depiction, if not fraudulent extortion, of the non-mundane Force (of) Thought in the name of one residual predicate.

The unilaterally sovereign one does not share (or, if it does, it does so only by an illusory residue involving a theoretical incompleteness) its indivisible power (of) effect with any predicate withdrawn from Logos or from the World, and it belongs to none. Even when Laruelle grants this sovereignty to ordinary man, or to man-in-man, he exposes non-philosophy to an accusation of anthropocentrism (and what ó Maoilearca's work posits in his book is precisely the possibility of a non-human thinking from within the non-standard matrix). The one (and its slightest epekeinomorphic divergence with regards to philosophy) holds sway from an absolutely privileged position in a hierarchic topology of thought over the only empty cell (of the) Real that it (is), among a neutralized Hell of an ideological mesh of illusions, of a philosophical compound of denials, of dizzying mixes of transcendences in which our theoretical World consists. But what the one holds sway (over), prior to whatever and in the last instance, is itself - because of its mystic inherence (to) itself. And as 
such, it is subordinate, and at a pinch even coordinate, to nothing.

The impregnable asymmetry and the absolutist haughtiness which characterize the syntax of the theoretical structure described above might surprise many of Laruelle's contemporary readers, especially those who had the chance to encounter him and to get acquainted with the discreet and nice person that he is, and even more so the few who had the chance to listen to his teachings or to work with him in any way. Even when dealing with a highly technical point of metaphysics, or when explaining the traits of some thinkers whom he would spend time analyzing, criticizing or deepening, Laruelle has always appeared to be far from arrogance, selfsufficiency or contempt. Yet there are obvious traces of the prowess of Nietzscheanism in Philosophy I, and there is some flagrant condescendence toward philosophers' self-deception or semi-blindness when Laruelle analyzes (and sharply abstracts) the mechanisms of their processes throughout most of his books - and sometimes with an amusingly cruel sharp pen. Let us quote one of the impressive early footnotes to give a taste of the initial aggressive-affirmative style Laruelle was using in his earlier works in the neighborhood of Deconstructionism and Differentialism. In the following quote, he is dealing with the old doctrines of liberation (Marxism, psychoanalysis) which yet require the apology, voluntary or not, of the Master (and the auto-position of Mastery) as a face of the reactive other inspiring love rather than subversion. The quote begins "[a]gainst parachristian and dualistic (religious) reactions that make the misery of the conjuncture..." and segues into a footnote here:

[Footnote 3] 1976: L'Ange [The Angel] (Lardreau and Jambet) and Marx (Michel Henry: Marx, "one of the first Christian thinkers"). There is, of course, almost no connection between the dualistic aspiration of the former and the strictly founded dualism of the latter. But the dualistically religious essence of these two works marks their mutual belonging to the misery of the conjuncture, which is fully impregnated with a spirit of reaction against Marxism, with a reactive desire for its destruction. These reactive rebellions are not to be confused with an active-affirmative destruction of Marxism by the recourse to Nietzsche. The conjuncture, like everything else, is cut in two, split by the other, even if it be covered with a mutual appearance of anti-Marxism. It is certain that Marxists will fall for this... nothing, however, is more repugnant to us than the disillusioned militants of a cause that has no longer their 
love. Old wounded and abandoned Marxists, young Marxists back from the ideological front, Freudians seized by timidity, Structuralists adrift; Lacanians who have suffered under the Master and are coveting Nietzsche: it is a bidding war to see who will, under the spotlight, expose to others his wounds with the least shame. We have no reason to love them, these twisted and disappointed minds, these limp intelligences whose palinode echoes around them and whose very reason for philosophizing is summarized in saying: I was the one who has suffered the most... understand me... ${ }^{21}$

We can guess that with such Nietzschean ways of looking down on his contemporaries (structuralists, Marxists, Heideggerians, Freudians...), Laruelle has begun quite a solitary career. We hear in his former texts so much of the cold halcyonian wind; his irony is so sharp and ruthless; his technical virtuosity is so implacable that we could ask if he would not be himself two-sided as a man: a charming, thoughtful and kind-hearted person on the one hand; a devastating, merciless and stark writer using a scalpel as a pen, on the other hand (but generically fused under which one of them?).

21 François Laruelle, Nietzsche contre Heidegger. Thèses pour une politique nietzschéenne (Paris: Payot, 1977), 62-63.

\section{The Extraordinary Man and the Rising of His City}

In fact, Philosophy I was not the most solitary path in Laruelle's course of thinking. It was not precisely beginning down the path of loneliness when he gathered prominent authors (Maurice Blanchot, Edmond Jabès, Mikel Dufrenne, Paul Ricœur, Jean-François Lyotard, Jacques Derrida...) around Levinas' work, ${ }^{22}$ published astonishing virtuoso articles in Georges Bataille's illustrious journal critique (such as "Le style di-phallique de Jacques Derrida" ["The Di-phallic Style of Jacques Derrida"] and "La scène du vomi ou comment ça se détraque en philosophie" ["The Vomit Scene, or, How It Goes Wrong in Philosophy"] ${ }^{23}$ ), and was interviewed by most of the leading deconstructionists. ${ }^{24}$ However, hanging out with Derrida and his friends was not precisely a good way to make academic friendships because deconstruction had also raised a lot of animosity around itself. (Derrida was not that influential, especially in the French university system: he had not even obtained a doctorate until 1980.) Choosing to

\footnotetext{
22 François Laruelle (dir.), Textes pour Emmanuel Lévinas (Paris: Jean-Michel Place, 1980).

23 François Laruelle, "Le style di-phallique de Jacques Derrida," Critique, No. 334 (1975), 320-91; François Laruelle, "La scène du vomi ou comment ça se détraque en philosophie," Critique, No. 347 (1976), 265-79.

24 Laruelle, Le déclin. In fact, we cannot exclude that ending this book with a series of questions was rather an editorial constraint than a personal choice of the author.
} 
flirt with deconstruction was a pretty good way to become marginal, and Laruelle was doing a little more than flirting.

So when he began to turn his former approach into an interest toward the immediate givens of unary multiplicities (rather than continuous multiplicities, as in Bergson), toward the transcendental cut as dispersive a priori, ${ }^{25}$ i.e., toward the essence of minorities as the one (when everybody around was just beginning to take full stock of the ontological and ethical articulation of the other), when he began to open a severe critique toward Philosophy as the zenith of authoritarian Mastery exerted over ordinary man, ${ }^{26}$ which led to the publication of the highest technical and critical introduction to the theory of difference ${ }^{27}$ by Les Presses Universitaires de France, and when he took an unpredictable radical leap that

\footnotetext{
25 François Laruelle, Le principe de minorité (Paris: Aubier Montaigne, 1981). The "Foreword" of this book has been translated by Edward Kazarian and is available online at Dark Precursor, September 1, 2013, WWw. darkprecursor net/2013/09/01/francois-laurelle-leprincipe-de-minorite-foreword-in-english. A large extract of the same book is also translated: François Laruelle, "The Decline of Materialism in the Name of Matter," trans. by Ray Brassier, in The Non-Philosophy Project, 159-69.

26 Laruelle, A Biography of ordinary Man.

27 François Laruelle, Les philosophies de la différence. Introduction critique (Paris: Presses Universitaires de France, 1986); English edition: François Laruelle, Philosophies of Difference: A Critical Introduction to Non-Philosophy, trans. by Rocco Gangle (London and New York: Continuum, 2010).
}

overthrew the twentieth century's complete set of Thought, he lost a lot of support and a few friends in the move. As Jacques Derrida referred to this about thirty years later, "no one understood what he did."28

Fortunately enough, by that time he had an editorial shelter at Aubier, initially with the book series Analyse et raisons, founded by the renowned author and professor Martial Guéroult, specialist of Descartes, Spinoza, Malebranche, Fichte, practitioner of high-standard internalist methodology, and creator of Dianoematics, his posthumous theory of philosophical history. At least he would be able to publish some of his books among other publications of contemporary researches and translations. At that time with Aubier, he created his own series, Res. L'invention philosophique, where he could host the works of some of his contemporaries (Gilbert Simondon, Serge Valdinoci, Gilbert Hottois, Daniel Nicolet, Abel Jeannière, Anne Cauquelin, François Foulatier, etc.). But he was longer able to be forgiven for having so quickly short-circuited the embattled paths over which old opponents had bitterly fought for decades, and for treating those opponents, from that moment on, all too playfully and with too much of a virtuoso inconsequence.

\footnotetext{
28 Remarks made on March 8, 2003, during a session at the Collège international de philosophie, "Hommage à l'œuvre de Michel Henry. Ce qui $n^{\prime}$ est pas du grec (A. David, J. Derrida, D. Franck, J.-L. Marion, J.-L. Nancy, N. Depraz, F.-D. Sebbah)," 29, Collège international de philosophie, WWW.ciph.org/IMG/pdf/memoire_orale_1983-2017-2.pdf .
} 
By that time, Laruelle was still try- Figure 2. Laruelle's 1980s self-published journal titled ing to set up a research program at the In- Pourquoi pas la philosophie?. ternational College of Philosophy, newly created in 1983 by Dominique Lecourt, Jacques Derrida, Jean-Pierre Faye and François Châtelet. But what bears witness the most to his solitary posture of work is the self-edited journal Pourquoi pas la philosophie?, which he began composing and distributing on his own, from April 1983 until october 1985. It was a six-issue, old-fashioned and typewritten publication - a quite inventive and incisive development of thought which defined and sketched the whole of nonphilosophy: from a thinking Science which is theorematically determined by Multiplicities as People (a science illustrated by the analysis of Decision) to the prospecting practice (of) Future by means of Hyperspeculation, i.e., philo-fiction. ${ }^{29}$

${ }^{29}$ Aksayam, \#TRANSISTOR.

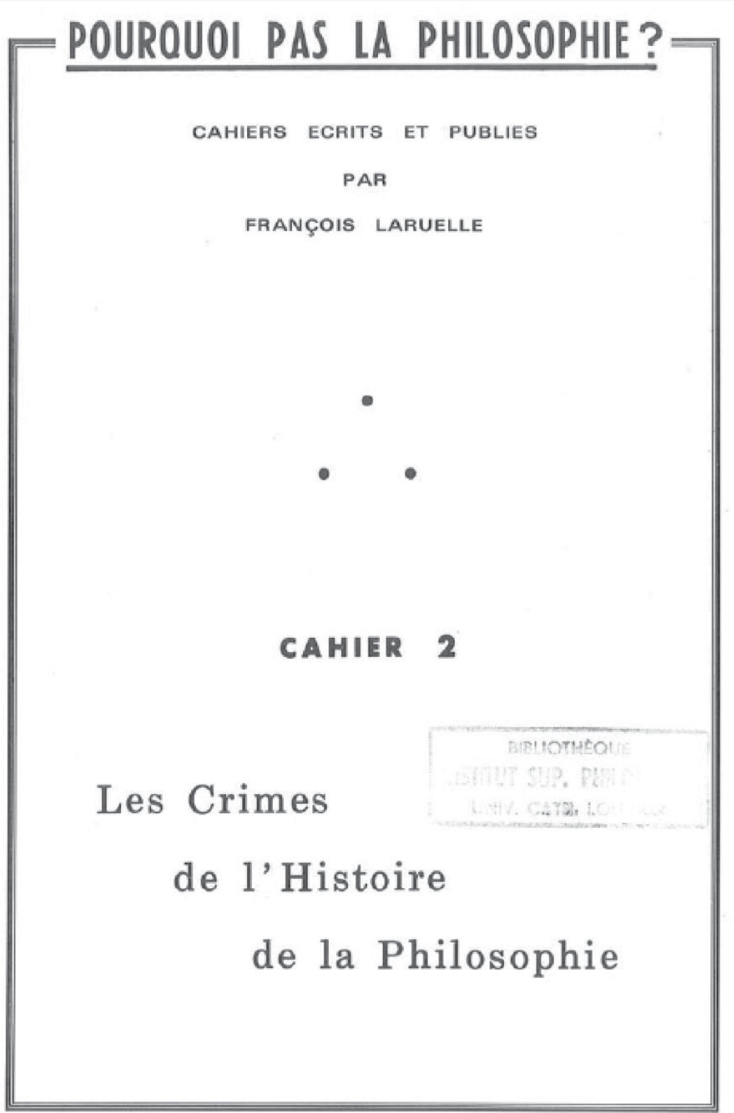

Octobre $1983-20 \mathrm{Frs}$.
It was only in 1987 that Laruelle found himself surrounded by a group of researchers with a new publication project, this time a collective one: La décision philosophique. What we could call the very first collective of nonphilosophers took shape around this publication, with members that would leave their marks in many disciplines: Maryse Decan, Laurent Leroy, Jean-Marc Lemelin, AnneFrançoise Schmid (whom we know very well now due to her important work in epistemology), Maryse Dennes, Tony Brachet (who developed the first insights about nonpsychoanalysis), Vincent Maclos, Daniel Nicolet (who played a major role in Wittgenstein's reception in France), Serge Valdinoci, Gilbert Kieffer (who established the first breakthrough 
toward non-æsthetics), Stéphane Douailler, Alain Arvois, Manuel Sumarès, Isabelle de Mecquenem, Patrice Vermeren or Philippe Petit (probably the most senior student of Laruelle and his most regular friend in the French editorial world of journalism). ${ }^{30}$

What has to be underlined is that this life-changing publication has been particularly decisive for Laruelle's writing: it was the place where experimental texts emerged as a specific praxis of non-philosophy. ${ }^{31}$ But this first collective has led also to two major publications: La non-philosophie des contemporains, which confronts Althusser, Badiou, Deleuze, Derrida, Fichte, Kojève, Husserl, Russell, Sartre and Wittgenstein, and within which Laruelle is credited with having signed an article using the byline of Tristan Aguilar; ${ }^{32}$

30 Probably certain names are missing here. The complete archaeology remains to be done, and archives needed for such a task have not been gathered yet. However, we have to thank Étienne Brouzes for his friendly patience in providing a trove of documents and data, without which this text could not have been composed.

31 Fortunately, the English-speaking world has access to this amazing translated anthology: François Laruelle, From Decision to Heresy, ed. by Robin Mackay (Falmouth: Urbanomic, 2012), which has gathered, next to some of the prominent theoretical excerpts taken from Laruelle's books, most of those published experimental texts that are scattered and hard to find in France.

32 Le Collectif Non-Philosophie, La non-philosophie des contemporains. Althusser, Badiou, Deleuze, Derrida, Fichte, Kojève, Husserl, Russell, Sartre, Wittgenstein (Paris: Kimé, 1995); Tristan Aguilar, "Badiou et nonphilosophie: un parallel," en Non-philosophie des contemporains, 37-46; English edition: Tristan Aguilar, and a far more well-known volume, Dictionary of Non-Philosophy, which turned out to be deeply impregnated by the rupture of Philosophy III, and which put an end to the editorial activities of this collective as such. ${ }^{33}$ This would mark the termination of a period that lasted about 15 years, the longest among Laruelle's enumerated Philosophies.

But although the first collective experienced something of a diasporic development - the scattering of some members, dormancy for others, or simply disaffection for a few Laruelle would not be alone anymore in the same way he had been at the beginning of the 1980s. As he reached the academic status of full professor, a new generation was gathering around him: former students who prolonged their postgraduate studies with him as a mentor and who moved to non-philosophy as a matrix that had already been constructed, aside from the usual philosophic apparatus, i.e., as a place from which to engage with a historical background. A lot of them had discovered non-philosophy, which was not exactly welcomed inside academic programs, through recorded courses that Laru-

"Badiou and Non-Philosophy: A Parallel," trans. by Taylor Adkins, Speculative Heresy, March 6, 2010, www. speculativeheresy. wordpress . com/2010/03/06/translationof-laruelles-badiou-and-non-philosophy-a-parallel. 33 François Laruelle et al., Dictionnaire de la nonphilosophie (Paris: Kimé, 1998); English edition: François Laruelle et al., Dictionary of Non-Philosophy, trans. by Taylor Adkins (Minneapolis, Minnesota: Univocal, 2013). 
elle was broadcasting via his university's long-distance learning programs. This collective of youngsters would soon be christened as the "Heretical Disciples" as they published their first volume of articles in 1998.

Juan-Diego Blanco, the first author to publish an introductory study on Laruelle, carried out at the Catholic University of Louvain under the supervision of Ghislaine Florival, was soon joined by Hugues Choplin, who was destined to become one of the most accurate specialists of contemporary French thought, and by Gilles Grelet, Mathias Lebœuf, Didier Moulinier, Laurent Nadot, Virginie Patoz, Laurent Salbert. Then, in the following years, more would gradually join them: Étienne Brouzes, Marc Develey, Jean-Michel Lacrosse, Sathya Rao, Boris Sirbey, Sylvain Tousseul, Sophie Lesueur, Sylvain Letoffé, Jean-Baptiste Dussert, Patrick Fontaine, and many others. But two things had changed in the meantime.

The first of these changes was the technological evolution between the two generations of non-philosophers, which becomes explicitly clear when we pay attention to dates: the turn to Philosophy III coincides with the rapid worldwide spread of the internet. The second change, at a very different level of depth inside theory, is closely coupled with Gilles Grelet's work with Laruelle in the process of writing his dissertation and also in- volved the proximity and companionship of the still unknown Ray Brassier: the plan to create the International Non-Philosophical organization (Organisation Non-Philosophique Internationale, hereafter ONPhI) was formulated during Grelet's thesis defense in December 2002 as a necessary "rectification" of the academic and mundane use of non-philosophy.

Regarding the internet development, as a French trailblazer of blogging, Didier Moulinier played a major role (and still does) in the early presence of non-philosophy on the web, but also for teaching philosophy, europanalysis, elementary poetry (poésie élémentaire) and philosophy publications, among other skills in centralizing data and broadcasting information. He soon became, and remains, the best access point to a recent and complete French bibliography of Laruelle, ${ }^{34}$ but he is also well-known for the lexicons he prepared, especially those which pursue the development of non-psychoanalysis. Following him, many other authors contributed to the blossoming of non-philosophical websites: from Sylvain Letoffé's Cahiers $\left(d^{\prime}\right)$ étrangers [Notebook of the stranger] and sophie Lesueur's uni(s)-vers [uni-(ted)-verse], to Jean-Michel Lacrosse's non-mondaine [nonworldly] or Alessandro Bertocchi's pensée-de-

${ }^{34}$ Didier Moulinier, "Bibliographie de François Laruelle," La non-philosophie, 21 octobre 2008, www.la-nonphilosophie.blogspot . com/2008/10/bibliographie-defranois-laruelle.html. 
nature-à [thought-likely-to or in-the-natureof-thou+ght]. And by this time, new printed collections began to support non-philosophical research: first of all, Éditions Kimé, founded by Béatrice Charrié in the 1990s, with their Bibliothèque de non-philosophie; or the more recent Éditions PETRA, which started their series Transphilosophiques around 2002, while other more established publishers opened their existing collections to single book publications of Laruelle (Mardaga, Exils, Textuel, Le Cerf, Fayard, etc.).

Yet the advent of the ONPhI also coincided with the use of the internet as a broader medium at the precise moment when gifted characters joined the project, such as Marc Develey, who graduated in mathematics and became a specialist in non-linear optimization of algorithms applied to micro-processors, and Étienne Brouzes, a PHP developer and art school student. The latter became the webmaster of all the ONPhI internet outlets (as well as of many of the blogs mentioned above) and also became the publishing designer of the most recent nonphilosophical printed journal so far, PhiloFictions, this time with an international scientific advisory board. The international spread of non-philosophy has entered the phase that we know today, with the acceleration that we are witnessing, through the influence of social networks and the numerous translations of Laru- elle's work during the past ten years, opening up an accumulation of international secondary literature.

But underneath this widening of non-philosophy's influence, and the building of an intense international research network, the ONPhI was also the theoretical theatre of a profound change of style in Laruelle's thought and, consequently, in his writing, a change that we can assess rather literally as a crucial turn. This is the non-religious turn which characterizes the period that lasted from 2002 until 2008 and the explicit penetration of the heretical (then messianic) themes within the matrix of expression and conceptualization that nonphilosophy adopted during Philosophy IV - after which Laruelle ceased to number the ensuing evolutions of his work. Concerning this turning point of the theory, a large amount of texts and documents (among which those that have been published and discussed on the ONPhI website), many emails and letters should be examined in order to clarify the role of each actor who was involved in the theoretical intensification that happened in the operations (in a military sense as well) that the ONPhI was initially meant to deploy .

In a very recent interview, Laruelle was asked about what he had to go through - more so than any other author of his generation particularly when it came to work in college 
setting, group and team work, or journals and collectives, and if this collegial work had an impact on his writing, on his themes, on the turning points of his research or on the corrections that he found important to make in his project. Laruelle answered that he was intrigued by "such a question," because he had not "ever thought about it in such a clear form" :

I always thought of myself as extremely solitary, as an isolated worker - a Gnostic surrounded by the whole philosophical tradition of the world. I always felt at the extreme point of intellectual loneliness, but many of us have the same experience. The philosopher likes to have disciples, but in fact he is especially in need of friends. I call a disciple the one who betrays me, and a friend the one who betrays me by remaining faithful. It is not within the reach of us all to know how to make a betrayal out of our power of friendship. My friends are the room of echoes in which I work. Besides conceptual materiality, there is an affective materiality that is a true "setting" ["milieu"] of existence. ${ }^{35}$

35 François Laruelle et Vincent Citot, "Entretien," Le Philosophoire, No. 43 (2015), 57-72.
This affective materiality that describes the assemblages of relationships (personal ones as much as, more broadly, social or environmental), within which the doctrine and the architecture of Thought that Laruelle has elaborated grew, is not precisely thematized: neither as part of the syntax of experience, nor as part of the rigor of immediate Finitude which non-philosophy details. We can most likely assume that the struggle against mixtures and against Ideal continuities has surely determined a certain avoidance to underline any kind of relation in the non-standard matrix (especially any kind of other or otherness) or to somehow consider any intersubjectivity prior to the essential dispersion of beings and multiplicities. But more profoundly, we can relate such an absence to the reluctance expressed by Laruelle to acknowledge that the one could be a psychological experience, the reluctance to allow the Real to be psychologized. And maybe here we behold how Rigor can be a matter of strategy, Laruelle's point being that the one must be emphasized as a theoretical lived experience (defined in the frame of a science), not as a psychological lived experience; a generic and formal or symbolical lived experience, not a personal experience. ${ }^{36}$

So we have to accept committing a crime here. A partial one, but a crime that this text

36 Aksayam, \#TRANSISTOR. 
has somehow already committed since its beginning, one of those that Laruelle points to as "the crimes of History of Philosophy."37 But as soon as we would delight in looking at the genetic process that orchestrated the production of non-philosophy, not only do we have to make a jump out of the inner movement of attention that non-philosophical discourse drives in the doctrine, but we have to also deal with contingent and contextual materials that are much further away from the transcendental gestures and immediacies (of) Thought that Laruelle's matrix relishes considering. Perhaps in doing so, we are part of the everlasting crime that the History of Philosophy is guilty of, that which Laruelle denounced in the programmatic publication Pourquoi pas la philosophie? in a different context, in the French academic situation thirty-five years ago. But digging deeper into the archives involved, with the different turns that the theoretical deployment of nonstandard thought underwent, might open a few barely known aspects of its emergence, broadening our understanding and our appraisal of what we already esteem as a masterpiece of art.

\footnotetext{
37 "History of Philosophy is the entire set of theoretical and pedagogical technologies that make it possible to subject individuals, not to a class or even to a State but to state-philosophical difference as 'major' paradigm." François Laruelle, "Les crimes de l'histoire de la philosophie," Pourquoi pas la philosophie?, No. 2 (octobre 1983), 35-36, reproduced in Aksayam, \#TRANSISTOR.
}

And it might also raise uncommon questionings about aspects of related problematics that are not usually approached inside theory but are connected to Laruelle's own personal journey, as well as to the future of the discipline and method that he has offered to his contemporaries and to his intellectual heirs.

\section{Fallen Angels: Relating the Encounters of Invention}

Having a look at the intersubjective past and present of non-philosophy - more than just soliciting supplementary amounts of theoretical positions, historical controversies or avantgarde admonitions around methodological or axiomatic endeavors - will also unfold the coextensive network of affects that is part of a collective doctrinal construction (as much as a conceptual and logical mesh can), on a sensitive and fragile, though intense, theatre of relationships between creators. ${ }^{38}$ And since Heresy constitutes a major figure depicting Minorities in the discourse of Sufficiency, at least since Laruelle's 2002 Future Christ, which inaugurated Philosophy IV, ${ }^{39}$ it is above all interest-

38 This theatre has been once curiously put on stage in a hermetic play, Rosalie Superstar, by Foutre de Dieu, which follows each period of non-philosophy to build an intensive drama of compulsive abstractions among intersubjectivities. See Foutre de Dieu, Rosalie Superstar, en Omajajri (Châlons-en-Champagne: Cynthia 3000,2007 ).

39 François Laruelle, Le Christ futur, une leçon d'hérésie (Paris: Exils, 2002); English edition: François 
ing - while looking backwards at the path that non-philosophy has travelled in its historical emergence - to pay attention to how dissidences have been dealt with in Laruellian discourse, when idiosyncratic non-Laruellian characters emerged among non-philosophers.

In fact, the management of dissidences in collectives and among disciples has a lot to reveal about the affects of Democracy, which non-philosophy is able to promote or call its members to improve on. of course, we can argue, and effectively we have to, that questioning non-standard thought in this way may imply taking stock of the mundane parameters of relationships, like empiricist psychologies, and it consequently implies taking the risk of stepping back into the worst of former philosophical habits. But, for what may be somewhat hard to measure for contemporary readers who are in the process of discovering Laruelle and nonphilosophy's protocols, the question of assessing which attitude is best equipped to deliver its promises of Democracy or of freedom for inventive multiplicities remains open. ${ }^{40}$ And more

Laruelle, Future Christ: A Lesson in Heresy, trans. by Anthony Paul Smith (London and New York: Continuum, 2010).

${ }^{40}$ One of the most active bloggers among the readers who try to analyze the worldwide reception of non-standard thought and the opportunity to compare it with other French contemporary proposals (like Deleuze's, Badiou's, or Latour's), quite famous on the internet, is Terence Blake, a.k.a. "Agent Swarm," who is peculiarly concerned by these questions and refuses to accord any prominent deeply, the theoretical options, the doctrinal manifestations or the methodological choices manifested by the dissidents in the different lineups of the precisely dated variations of the non-philosophical collectives will also reveal how heterodox approaches (of immanence, of invention, of mysticism, of rebellion, of how to organize research or activism, etc.) formulate a very different point of view on nonphilosophy - but from the inside - and what it means to confront divergent standards of rigor when trying to promote a new collective and open praxis of Thought.

Let us consider two different historical emergent figures among non-philosophers who have accompanied Laruelle during some of his years of labor. Both were, though in very different ways and at different periods, deeply involved in the theoretical development and the intellectual promotion of non-philosophy, and both were very close to Laruelle. Both were bringing major theoretical propositions and a major long-lasting wave of creativity into the Laru-

position in the debate to Laruelle's perspective and methodology over other attempts to improve our conceptualizations of Democracy and its actualization. For example, Blake began to argue on the point that, based on non-philosophers with whom he has been in contact with throughout the years, non-philosophy is not as likely to support Multiplicity than the Deleuzian deterritorializing schizo-assemblages, which provide and articulate a more open ontological pluralism, specifically by having stopped being a philosophy of Difference, to adopt a philosophy of multiplicity that eludes the critique formulated by Laruelle. 
ellian construction. And both experienced, but clearly differently in each case, some kind of resistance, some difficulties in having their own approach recognized as much as they were recognizing and promoting Laruelle's, and even some sort of stonewalling or explicit rejection that finally led both to take some distance, and more or less walk away, from further construction within non-philosophy.

\section{III.A. The In-blind Thought that \\ Fuels Civilizations}

The first of these characters is serge Valdinoci, who was already mentioned above as an early collaborator of La décision philosophique in the 1980s. Although of course very hard to re-enact, it seems the encounter between Laruelle and Valdinoci took place around 1984, as attested by the review Valdinoci wrote of Le principe de minorité [The Minority Principle], which was published in 1981. His assessment of Laruelle's research is clear: while comparing Laruelle to John of the cross because of the "active Night," Laruelle intensifies his theorization in this work, which was born from a "difficult and absolute enterprise" and is described as a "foreign book" that deserves patience and respect as to be near approached. ${ }^{41}$

41 "Un livre étranger": contrary to the usual translations, when used as an adjective, Laruelle's Étranger in French means "foreign" rather than "strange" (cf. Laruelle, Théorie des Étrangers). What is remarkable in this book review by Valdinoci is to observe that
When Valdinoci met Laruelle's line of theoretical exploration, he had already published with Nijhoff. Validnoci's doctoral dissertation is titled Les fondements de la phénoménologie Husserlienne [The Foundations of Husserlian Phenomenology], ${ }^{42}$ and he was mentored in 1979 by the same professor who also advised Laruelle - Paul Ricœur - in a period when there were no longer any specialists or researches of Husserl in France, since everybody had followed the Heideggerian mood of the Zeitgeist. And Valdinoci was completing Le principe d'existence [The Principle of Existence], an inquiry into psychiatry and phenomenological theory of psychopathology (Ludwig Binswanger, Medard Boss, Eugène Minkowski, Wolfgang Blankenburg) when he participated in creating the first collective of non-philosophers. Although closer to Raymond Ruyer (1902-1987) rather than to the stars of French Theory (because initially Ruyer was his teacher at the University of Nancy), when Valdinoci asserted that the "pathological state is perhaps pure existence," ${ }^{43}$ he was already in the neighborhood of Laruelle's dispersive cut inside Being. Yet he was holding on to psy-

Laruelle would not use such a vocabulary before the late 1990s. See Serge Valdinoci, "Notes critiques: Le principe de minorité par François Laruelle," Revue de Métaphysique et de Morale, 89e Année, No. 2 (avril-juin 1984), 268-70. 42 See Serge Valdinoci, Les fondements de la phénoménologie Husserlienne (Hague: Nijhoff, 1983).

43 Serge Valdinoci, Le principe d'existence. Un devenir psychiatrique de la phénoménologie (Dordrecht: Springer, 1989), 1 . 
choanalytical inquiries about the embodiment of the deepest experience, which tallies with both Michel Henry's critiques of ontological monism from the point of view of an incarnated ipseity, ${ }^{44}$ and with Charles Blondel's approach of the cœnesthetic "pure psychological," which was of major importance for Minkowski's phenomenological psychiatry. ${ }^{45}$

Valdinoci's contributions to La décision philosophique were substantial. From the opening editorial ${ }^{46}$ to feature articles, ${ }^{47}$ his writings were always in-depth analyses and dense

\footnotetext{
${ }_{44}$ Michel Henry, L'essence de la manifestation (Paris:
} Presses Universitaires de France, 1963); English edition: Michel Henry, The Essence of Manifestation, trans. by Girard Etzkorn (Hague: Nijhoff, 1973).

45 Charles Blondel, La conscience morbide. Essai de psychopathologie générale (Paris: Alcan, 1914); English edition: Charles Blondel, The Troubled Conscience and the Insane Mind, trans. unspecified (London and New York: Routledge, 2014). See also German E. Berrios and Filiberto Fuentenebro de Diego, "Charles Blondel and La conscience morbide," History of Psychiatry, Vol. 8, (1997), 277-95.

46 Serge Valdinoci, "Tout va bien!," La décision philosophique, No. 7 (1988). We have to mention that La décision philosophique had only odd numbered issues. The even numbers of the publication were single letters mailed to subscribers or were left in few specific bookshops.

47 Serge Valdinoci, "Au-delà du principe de philosophie," La décision philosophique, No. 1 (mai 1987), 50-69; "L'Un, une nouvelle condition de pensée," La décision philosophique, No. 3 (décembre 1987), 39-49; “La naissance de la science à l'époque de la philosophie, en Europe," La décision philosophique, No. 5 (avril 1988), 5-39 (here Valdinoci is given the opening article in the journal); "La science de l'homme immense: une analyse non-platonicienne," La décision philosophique, No. 9 (1989), 65-79. explorations of the experiences of Thought, of technical aspects of the abusive withdrawals of Philosophy from the Real (in the sense of "forfeitures"), or of programmatic propositions for the development of research, always caring and endeavoring to render closely Laruelle's thought or his analyses, but offering as well very innovative insights, astonishing original overviews or stunning unexpected connections in highly overwhelming formulas. The only rubric to which Valdinoci offered a contribution was the one called "Textes expérimentaux," in accordance with and consistent with his reluctance to any kind of literary play with words, fancy language or hollow rhetoric, which he has always found so invasive and pointless in continental twentieth-century philosophers.

Both knew they were launching something, something unlike anything else, something to be reckoned with. They began to undertake a very passionate and symbiotic work in multiple directions, with Valdinoci joining Laruelle in special sessions at the International college of Philosophy, publishing a thematic feature article about La décision philosophique in the College's Le Cahier ${ }^{48}$ and spearheading in his own research the attempt, as he says in his own

48 See the section "Études" with texts by Laruelle, Valdinoci and Pierre-Jean Labarrière in Le Cahier (Collège international de philosophie), No. 4 (novembre 1987), 25-66, and specifically Serge Valdinoci, "Derechef, qu'est-ce que s'orienter dans la pensée?," in ibid., 4151. 
words, to access, in the dead of Night, the black, negative, inhuman conditions that make the ordinary of man. All of this felt like a heroic period. They even confronted together Alain Badiou at Villa Gillet (the famous international multidisciplinary center in Lyon), and Valdinoci was approached to become the headmaster of an emerging non-philosophy school, the first of its kind. The intensity of their collaboration can be witnessed in the only published text Laruelle had ever co-written with anyone that we know of: "Lettre ouverte aux professeurs de philosophie" ["Open Letter to Philosophy Teachers"], which they wrote together in 1988 in order to invite readers to join the group behind La décision philosophique.
Il ne peut donc être question que $L a$ décision philosophique se fige en gardienne d'un néo-académisme. Afin de préparer effectivement la diffusion au sens élevé du terme, une puissante action-philosophying est appelée de nos vœux. Il faut saisir la chance que libère la destruction des célèbres " horizons incontournables " du discours et de la pensée et, pour nous, saisir cette chance signifie : resserrer au maximum les distances qui séparent actuellement la production et la réception. Tel est le mot d'ordre, si besoin est. C'est pourquoi, outre l. les textes scientifiques et 2 . les textes de sensibilisation pédagogique, 3 . une nouvelle pratique du genre philosophique est proposée sous forme de textes expérimentaux et de philo-fiction. Il s'agit d'une pratique qui conduirait vers sa propre théorie en exposant les règles $\mathrm{d}$ 'invention, en rendant transparente l'écriture du genre philosophique. La philosophie doit sortir de son habitus, de son inertie postsocratique et inventer de nouvelles pratiques textuelles qui ne soient pas seulement de consommation de textes déjà faits, mais d'invention et de production différentes.

Pour le collectif de La décision philosophique F. Laruelle et S. Valdinoci.

Figure 3. The last paragraph of Laruelle and Valdinoci's co-authored text, from La décision philosophique, No. 5 (April 1988), 126.

Deepening his own research and articulating that research in line with Laruelle's, Valdinoci explored, in accord with his viscer- 
al commitment to psychiatry, the patheme that impregnates Europe: as being the continental embodiment of a culture cradled by Philosophy's excision of the Real and constitutively immersed in its own hallucination. He calls the patheme the black proto-affection of knowledge. ${ }^{49}$ In 1990 this led Valdinoci to publish Introduction dans I'europanalyse: Krisis 2, transformer la phénoménologie de Husserl pour fonder la philosophie [Introduction into Europanalysis: Krisis 2, Transforming Husserl's Phenomenology in order to Ground Philosophy] in Laruelle's series Res. L'invention philosophique, offering a method which transubstantiates Husserl's Krisis in order to penetrate the core difficulty of experiencing real thought as a conesthetic and deep-rooted interior affect, and in order to place therein the movement of the crucial human adventure, which is

\footnotetext{
49 Patheme refers to pathos and is an antithesis of Lacan's matheme (which is too much of a linguisticscentered theory in Valdinoci's perspective). As a matter of fact, we could say that in some way Valdinoci is in non-philosophy what Antonin Artaud was in surrealism - though his sense of absolute vertiginous dread can also remind of Georges Bataille, to whom he dedicated a tremendous conference in 1997, see Serge Valdinoci (dir.), Georges Bataille: L'économie du sacrifice (Reims: Le Clou dans le fer, 2004). But Artaud, as if he were theorizing psychopathology itself, was using clinic (examining a lying [reclined] patient) and the psychiatric clinical relation (the naked reliance on a caregiver to take in one's suffering) as a foundational metaphor for the lived-Cut, for the living state of reduction: a protophor (unlike Laruelle's, Valdinoci's use of metaphor is rather related to Max Black's - to whom Ricœur introduced him - than to Derrida's).
}

a mystical internal embedding. This was the opening of an intensely driven productive period leading to what was called the Fire Trilogy: Vers une méthode d'europanalyse [Toward an Europanalysis Method] (1995), La traversée de l'immanence. L'europanalyse ou la méthode de la phénoménologie [Traversing Immanence: Europanalysis, or, the Method of Phenomenology] (1996), and La science première. Une pensée pour le présent et $l^{\prime}$ avenir [First Science: A Thought for the Present and the Future] (1997), the massive deployment of an immanentist theory of invention. 50

Despite having very different writing styles and fairly different motives of inquiry, Laruelle and Valdinoci were theoretically very close at the beginning, and this can illuminate the reason why it so happened that their encounter developed as an intimate confluence, each respecting above all the uncompromising cutting-edge thinker he had come across. Stat-

\footnotetext{
50 Serge Valdinoci, Vers une méthode d'europanalyse (Paris: L'Harmattan, 1995); La traversée de l'immanence. L'europanalyse ou la méthode de la phénoménologie (Paris: Kimé, 1996); La science première. Une pensée pour le présent et I'avenir (Paris: L'Harmattan, 1997). Presently, translations of europanalytic texts are very rare. One can consult the translation of the opening of vers une méthode d'europanalyse, as well as extracts from La science première, by Jesse Newberg (originally made available online on February 18, 2013 on Newberg's blog, which is now defunct) available online as: Serge Valdinoci, "Why Europe?," trans. Jesse Newberg, INgens, January 9, 2018, WWW.ingens.eu/index.php/pages/73europanalysis-english-version; and at Archive.org, web. archive.org/web/20130422180523/http://cups. zxq. net.
} 
ing that the cut is prior to the Idea, that dispersion is prior to any synthesis, or that there is an ordinary state of Reduction on whose behalf Thought has to positively abandon Logos, was pretty God damn heretical in a traditional philosophical context, even after Heidegger's death. It was highly improbable that one would come to know someone reaching such a level of the work of Thought, someone who would take the same risk of being an outlaw of the principle of sufficient reason. They immediately had a sense of such luck. But the turn to Philosophy III would put an end to this long-lasting honeymoon period.

The shortest way to explain the difference between the two thinkers and between the two matrices of immanence they have erected is most likely to see those differences as already having been there from their earliest publications. ${ }^{51}$ Immanence has always been described in Laruelle's text as an indivisible power (of the) cut ("Immanence divides, transcendence en-

\footnotetext{
51 More profoundly, considering their intellectual profile and their respective manners of thinking, Laruelle could be perceived as being more Fichtean while Valdinoci as being more Hegelian. But the more accurate comparison would be that of Sartre and Merleau-Ponty, particularly because of the great work Valdinoci has been doing for so long on the late Merleau-Ponty, and because, when reading the first chapters of The Visible and the Invisible, and while answering in a very profound manner to Sartre's dualism, they sound as if talking about Laruelle. With such interiorized different characters, misunderstandings should have occurred between them sooner or later.
}

compasses," he says $\left.{ }^{52}\right)$; as a determining Identity undetermined by any otherness; and named, in as great an opposition as that of Being to beings could imply, the one. In tune with the possible descriptions of the one's essence, Valdinoci always insisted on the embrace (of) immanence, on its inexpugnable inherency (to) self, on its conflation "with its depth, its consistency, its flesh, its immediate (auto-) impression, and which therefore is not requisitioned as limit of an operation of extraction, of analysis,"53 but he insisted very little on its unary characteristics: rather than the one, Valdinoci preferred naming it the Inner, the Internal, the pure Autos (of) affect, or the Endon. ${ }^{54}$ That is why his thought was not con-

52 Laruelle, Le Christ futur, 65, quoted in Christophe Samarsky, "Sur la musique," en Naufrage sillonnes (pas $\left.d^{\prime} e l l e\right)$ (Paris: TheBookEdition/Collection arabesque, 2010).

53 François Laruelle, Philosophie et non-philosophie (Liège/Bruxelles: Mardaga, 1989), 37-79; English edition: François Laruelle, Philosophy and Non-Philosophy, trans. by Taylor Adkins (Minneapolis, Minnesota: Univocal, 2013), $33-79$.

54 Endon is a Greek root that means "internal," "inside." Valdinoci explores and uses this etymological radix (or prefix) to create a complete conceptual set: endoception, endoconcepts... This root is very common in medicine: "endoscopy," "endogenic," and so on. But above all, it became a major psychiatric concept when Hubertus Tellenbach (1914-1994), a German phenomenological psychiatrist wrote his great work on melancholia, see Hubertus Tellenbach, Melancholy: History of the Problem, Endogeneity, Typology, Pathogenesis, Clinical Considerations, trans. by Erling Eng (Pittsburgh, Pennsylvania: Duquesne University Press, 1980). We will see in the next pages the strange and capital role played 
cerned so much with the question of how to articulate Transcendence via unilateral determination in the last instance, via the (Non-)one or via cloning: there was no other side than the in-side, and he has never used the metaphor of Hell to describe the World but has used only the sense of chaos to describe the Universe in a blind state (condition) of invention. If we understand Unilaterality as the depiction of $X$ distinguishing itself from $Y$ which does not distinguish itself in return, then Laruelle was building on the distinguished side while valdinoci was building on the side which is not.

So when Laruelle brought up in 1996 the principles of a unified theory that definitively forbade saying anything about the one foreclosed to Logos, he swept away the complete non-philosophical Valdinocian theory of writing as an internal practice of ingestions of Logos by a general æsthesis (i.e., pre-noetic sensitivity, or, as he names it, Endoception, i.e., Impression); as an operative Reduction able to transubstantiate partes extra partes occidental representations into visceral pathemes, able to reach back to how concepts are initially impregnated by Endon. And in doing so, Laruelle de facto excluded Valdinoci's program for a mystical experimenting with black Thought. There was no longer a place for europanalysis in non-philosophy. The theoreti-

by melancholia and manic depression in the thought of Laruelle's dissidents. cal split was effective. From Valdinoci's point of view, Laruelle was just essentializing the Limit where there was no limit anymore, because there was no where, neither perceptive spaceTime nor unity, but merely immensity without borders and no outer part.

In fact, the only explicit and remaining traces of this period in Laruelle's books are the entry "Europanalysis" in the Dictionary of Non-Philosophy ${ }^{55}$ and the one and only footnote that can be found in Laruelle's Principles of Non-Philosophy. ${ }^{56}$ Knowing how rare footnotes are in Laruelle's texts, especially after Philosophy $I$, and that references to contemporary thinkers are even rarer, there could not be any higher way to pay tribute and express his respect to the intense companionship that brought them together to the deepest incursions into Thought. It turned out to be a hurtful wound. Valdinoci felt that his work was shortened to one sentence (yet a rather clumsy rather than a tactless one), which gave to europanalysis an identity that has been reduced in coordinates related to Philosophy - thus giving place to a kind of thought which was intimately foreign to any place. ${ }^{57}$ In that sense, it was a reason for

\footnotetext{
55 Laruelle et al., "Europanalyse," Dictionnaire, 69-71; Laruelle et al., "Europanalysis," Dictionary, 58-60. 56 Laruelle, Principes, 41; Laruelle, Principles, 304. 57 In fact, this footnote takes place on a page whose purpose is to bury Philosophy II, "this point is crucial," Philosophy will no longer be "dissolved, forgotten or critiqued and hastily rejected" (Laruelle,
} 
Valdinoci to feel wronged regarding the work of analysis and promotion he had always been doing for Laruelle's thought. From that perspective, the title that he gave to the third volume of the 1995-1997 trilogy, First Science, probably the most powerful book of mysticism written in the French contemporary field (it is huge, literally), can be interpreted as an implicit controversy and rival response to Chapter 2 of Laruelle's Principles: "'First Science' as Unified Theory of Science and Philosophy: Or, Democracy within Thought," ${ }^{58}$ although in its contents

Principles, 35). It is clear in this passage that Valdinoci's work is equated with Henry's philosophy. Non-philosophy is turning from absolute to radical. We already know, though admitting "the strictly founded dualism" of Henry's Ipseity of auto-affective flesh (see above), that Laruelle rejects it because of the empiricist remains that are kept in such an embodied theorization of immanence. This is also consistent with the reluctance to psychologize the one-Lived. But the question remains: Why does not Laruelle take into account the living flesh as a precise experience of Finitude, like Henry describes it when recalling Maine de Biran's sense of effort inside the lived Resistant continuous? And why does he not take into account in the same way Valdinoci's psychiatric Finitude of Sense (of hermeneutics) as this Finitude is felt (confronted) while traversing chaos? This is probably related to Laruelle's minimal investment in theorizing the body, especially since he had stopped theorizing the libido. On that matter, François Laruelle, Le concept de non-photographie / The Concept of NonPhotography, bilingual edition, trans. by Robin Mackay (Falmouth/New York: Urbanomic/Sequence Press, 2011) seems to position himself in a new set of descriptions (see below, and see also Narciso Aksayam, "Fudging Laruelle's Decision: A Historical Path toward a Non-Philosophical Body," forthcoming).

58 Laruelle, Principles, 37-78.
Valdinoci's book remains deeply respectful and mindful of Laruelle's breakthrough.

At that time, the Dictionary, which has been written by the members of the first collective, was a theoretical mess as compared to the new requirements of Philosophy III's unified theory. Laruelle performed an immense labor of writing to get to the point where every entry would fit with consistency the new lines of rigor which non-philosophy was inserting. Between the two thinkers, there would not be any strategic union without theoretical union. And it still remains a real affliction to look at Valdinoci's draft for the entry of "Affect," 59 which would not be given a place in the Dictionary because of its obvious transgression of an irremovable and newly definitive rule. Each one would carry on through their own path of thought, further, deeper, wider or more according to, but certainly with a new taste to be recognized and felt in Solitude.

Nevertheless, beyond those contingent misunderstandings belonging to the past of two masterpieces of French thought, sometimes (especially since the quantum turn of, let us name it, Philosophy $v$, although these names are sometimes no longer relevant under Laruelle's pen) non-philosophy still resounds with a suddenly surprising europanalytic accent. This is

59 See Serge Valdinoci, "Le manuscrit de l'article 'Affect,'' INgens, 28 mai 2018, WWw.ingens.eu/index.php/ europanalyse-continent-d-invention/80-serge-valdinoci-lemanuscrit-de-1-article-affect . 
particularly true when Laruelle develops his conceptions of the undulatory, the "immanental," the depth of the body, or generalized fractality:

... this fractality is not either manifest ed in geometric manner by a jagged profile, by spikes, angles, ruptures or points of interruption, by a symmetrical angularity occupying a surface as being flat; but by another type of excess that occupies the surface, yet as being deep, in so far as this depth is not in or of space, or behind the surface, but a depth peculiar to an extreme flatness for which the plane remains only an adjunct phenomenon of superficiality and of its own "intensive" depth. This excess is constituted by intensive "spikes" that the strict identification of the opposed predicates, peculiar to representation, produces, for example the representation of the appearance and of that which appears. ${ }^{60}$

60 Laruelle, Le concept / The Concept, 79. Some modifications of Robin Mackay's translation have been made here, in consideration of the difficulty of this passage. Non-spatial depth, excess, strict identification of opposite predicates and even intensive or qualitative depth are typical europanalytic topics, concepts or modes.

\section{III.B. The Sharpness and the Rigor of Discipline}

The second case of dissidence and heresy among non-philosophers is the one of the heresiarch in himself, i.e., the Rebel in himself, namely, Gilles Grelet. After evoking the living black Abyss with Valdinoci, let us now call upon a Meteor, a truly fulgurating comet. We have to recall that everything seems to precipitate in 1998, the year when the page of Philosophy II was definitively turned by the release of the theoretically unified Dictionary of Non-Philosophy. That same year, indeed just a few months later, a new collective book was to be published: Discipline hérétique. Esthétique, psychanalyse, religion [Heretical Discipline: Aesthetics, Psychoanalysis, Religion]. ${ }^{61}$

At this time, Grelet had been one of Laruelle's doctoral students since 1996, and he could be seen for several months in Laruelle's classrooms, listening to global topics like "Man and City" or to Laruelle's attempt to design a non-phenomenology in a seminar which was given twice a month. Laruelle's place was a little more consolidated within academia because he had published Principles of Non-Philosophy in Jean-Luc Marion's series and had reached the level of Professor. It was probably a moment for a brief recovery from certain aca-

${ }_{61}$ Le Collectif Non-Philosophie, Discipline hérétique.
Esthétique, psychanalyse, religion (Paris: Kimé, 1998). 
demic survival strategies, as well as from a major heart surgery which he had to undergo in 1992. And we can guess, according to the dates, that Laruelle was working on both Introduction to Non-Marxism ${ }^{62}$ and Théorie des Étrangers.

Among the ten essays of Discipline hérétique, only two were signed by former members of the collective: Gilbert Kieffer and Tony Brachet. All the other texts were productions from a completely new group, spanning non-philosophical effects from æsthetics to psychoanalysis, from geopolitics to poetry. ${ }^{63}$ one might say: "the usual" (or - but who would dare? - "the ordinary"), yet how accurate, how bold and how inventive those contributions were! However, when we arrive at the last essay, obviously something different was happening, a burning sharpness in the cutting of phrases, a radical and fierce recklessness in the sequencing of ideas, an unexpected radicality of thought, even in the use of references and in the insightful knowledge of Laruelle's writings. But above all, what was happening was someone able to say "I," and to undertake the hard-line

62 François Laruelle, Introduction au non-marxisme (Paris: Presses Universitaires de France, 2000); English edition: François Laruelle, Introduction to Non-Marxism, trans. by Anthony Paul Smith (Minneapolis, Minnesota: Univocal, 2015) .

63 In Discipline hérétique, europanalysis was even sort of mentioned in one and a half pages under the pen of Danilo di Manno de Almeida, but in terms which appalled Valdinoci's readers so much that it was hard not to suspect some kind of indirect reckoning, one last bitter twitch from their breakup. stance that comes with it. "Un bréviaire de non-religion" ["A Breviary of Non-Religion"] ${ }^{64}$ was the first step that Grelet was making into non-philosophy, and it was a resounding one.

Neither heresy nor non-religion had ever been posited this way in non-philosophy before. ${ }^{65}$ At the opening of the book, Laruelle lays bare the axioms of pure heresy, and redefines, in a still famous text, ${ }^{66}$ what he formerly called unilateral indifferent science as a radical Heresy as much as a Heresy of radicality. At the end of the book Grelet draws the lines of the discipline which he names theorism or non-religion, and which "can be told of Rebellion, of radical struggle against an implacable enemy: necessity, with its worldly horizon of corruption and of death, in which consists what I call Nihilism." 67

${ }^{64}$ Gilles Grelet, "Un bréviaire de non-religion," en Collectif, Discipline hérétique, 182-216.

65 In fact, if "non-religion" appears only once in the Dictionary of Non-Philosophy, under the entry "Other (non-autopositional other, non-thetic Transcendence)," the entry "Man (humans)" states for the first time that "[n]on-philosophy is a rigorous heresy: it makes of man a being-Unseparated (from) self, and thus Separatedwithout-separation from the World." Laruelle et al., Dictionary, 79. And the entry "Time-without-temporality (radical past, transcendental future, world-present)" ends with defining the "heretical time or the heretical conception of time, without history or becoming." Ibid., 148.

66 François Laruelle, "De la non-philosophie comme hérésie," en Collectif, Discipline hérétique, 7-23; François Laruelle, "Non-Philosophy as Heresy," trans. by Taylor Adkins, in From Decision to Heresy, 257-84.

${ }^{67}$ Grelet, “Un bréviaire," 182. 
As opposed to Valdinoci and his gigantomachic drought of chaos, Grelet is a man of few words, his writing tends to culminate in aphoristic formulas, and his publishing is very rare due to endless rectification. But, like Valdinoci, when they connected, Grelet had an intellectual background different from Laruelle's. Thus, if we want to sketch the direct line of ascendency which he belonged to, we must call upon the following lineage of teaching: Étienne Gilson (1884-1978), a Thomist specialist of Medieval philosophy, teacher of Henry Corbin (1903-1978), the first French translator of Heidegger and specialist of Shiism and Islamic mysticism, teacher of Christian Jambet (1948-), a former Maoist and author (with Guy Lardreau) of the book L'Ange [The Angel] ${ }^{68}$ (see above), the first teacher that Grelet met in philosophy. And it was precisely L'Ange that Grelet was appealing to in non-philosophy.

We have to understand that theorism is profoundly animated by a rare reluctance to culture and a rare indifference to the production of any kind of scientific knowledge (what could be another point in common shared with Valdinoci). What Grelet calls the Angel is the abolition in person of Law, the accomplished "realm" of Justice, since it has no image (of) self. Non-religion is the Rebellion-in-

68 Guy Lardreau et Christian Jambet, L'Ange. Pour une cynégétique du semblant (Paris: Grasset, 1976). man against foreclosed radical individuality; it considers cloning as the alienation of the heart of Man to the sorcery of Transcendence; and it makes of Non-Thetic-Transcendence-(of)self a dissolving force that is opposed to the spontaneous faith in a reciprocal determination of the Real, a faith on which the rationality of every World-Discourse relies, as sufficient $s(p)$ ecularity. In short, Grelet was asking how non-philosophy could be able to radically change subjects by changing their relation to any fate.

From a Lacanian apparatus ( R, S, I) and with a Blanchotian affect, what Grelet posits is a line of division between Pretense ("le Semblant") and Saintliness. "It is right to divide/divinize ourselves": here is the first statement that begins Déclarer la gnose. D'une guerre qui revient à la culture [Declaring Gnosis: On a war that comes Back to Culture], the first book published off his dissertation. ${ }^{69}$ But this line also divides the field of theorization of immanence: on the one side, philosophies of

69 Gilles Grelet, Déclarer la gnose. D'une guerre qui revient à la culture (Paris: L'Harmattan, 2002), 11. Readers must consider a second text by Grelet as a necessary complement to this book, especially since Laruelle takes its content into account in the answer he gives to Grelet's position: Gilles Grelet, "Antiphénoménologie," Revue philosophique de la France et de l'étranger, Vol. 129, No. 2 (2004/2), 211-24; English translation: "Anti-phenomenology," trans. by Kris Pender, no date, Academia, WWW.academia.edu/4624766/Gilles_ Grelet_-_Anti-Phenomenology. 
pure immanence (like Henry's archi-Christology) which absolutely negate Transcendence (i.e., Terrorism); on the other side, Laruelle's majoritarian non-philosophy that leaves Transcendence pretty intact (i.e., liberal Theoricism). A rightist deviation and a leftist one. ${ }^{70}$ Aside of those two, Grelet's theorism carries the requirement for any Rebel to be both the arrow and the target, that is, to be oneself the field where Transcendence is to be purified from its imposture (cf. Pretence): an immanent war field. ${ }^{71}$ What Grelet did in this very first essay was exactly what Laruelle had done with europanalysis: giving a place and identity to Laruelle's own practice by means of theoretical coordinates.

This introduction of the fiercest struggle against the World, expressed with such a rigor and generalized via religious themes (considering that Philosophy is just one possible dis-

\footnotetext{
${ }^{70}$ Grelet adds a third kind: Tourism, characterized by a superficial use of non-philosophy as mere pedagogical tool for academic philosophy learning.

71 "The Real is war" (Grelet, Déclarer la gnose, 66). To support this argument, Grelet quotes Christian Jambet: "the absence of foundation of the real, that is war itself; the forgetting of war, that is precisely the tragedy of nihilism; the incapacity to wage war, that is the sign of servitude." Christian Jambet, "Une lecture hégelienne," Cahiers de la torpille, No. 2 (mars 1999): Sommes-nous heroiques?, dir. par Cynthia Fleury et Yannis Constantinidès, quoted in ibid. In this war, agnostic Rationality is the enemy that hypostatizes Death into cultural Time (ibid., 80). The minimum imperative requirement of Rebellion is to suspend any belief in Death, the maximum one is to play the Angel (ibid., 95).
}

course of faith accorded to Transcendence among others, but precisely the most s[p]ecular of all), was acceptable for Laruelle, as he was himself working at this very moment on renewing his ties with Marxism. But moreover, we can easily imagine how Laruelle could have welcomed and greeted being challenged by a young worthy heir. The relation grew passionate and enthused but more comfortable than the former one with Valdinoci, because as a disciple Grelet's theoretical matrix was already more fitted into nonphilosophy's matrix than Valdinoci's could have ever been. Their respective works went closer and this co-construction reached its climax in 2002, the year of Grelet's thesis defense.

It is uneasy to grasp how much this coworking was decisive for the development of the religious metaphorism in Laruelle, which emerged as the turn to Philosophy IV, but it was surely determining. And Future Christ, the first book ever departing from the Principle of Sufficient Philosophy that afterwards discusses a Principle of Sufficient Church, was published in this same year. One thing is clear: Grelet's thesis defense is ONPhI's ground zero. Taking place on December $14^{\text {th }}, 2002$, Grelet's presentation in front of his jury was built like a military operation against the University, as an attack to recapture teaching from "the vampirism of spontaneous sufficiency."72 The aim

72 Gilles Grelet, "Soutenance de Nanterre," Organisation 
was to rectify non-philosophy by a usage of it and to make non-philosophy operational through theorism, which was described as the proletarianization and the radical militarization of theory rather than its theoricist reform. Grelet ended this presentation with the firstever reading of the articles and by-laws of the forthcoming ONPhI, which he had devised with Laruelle. ${ }^{73}$

As we explained above, given the internet at this historical conjuncture, in the following year (2003) the international organization was ready to be launched and fully operational. And there Grelet immediately developed his "activism of theory, the one which hauls the philosophy-form over the coals and which gives to non-philosophy its organizational sharpness."74 His proposal was immediately adopted and intensified by publications of other members (like Hugues Choplin's or Erik Del Bufalo's). The international scope of the ONPhI gathered also rising figures of cutting-edge thought, such as Katarina Kolozova and, as already mentioned

Non-Philosophique Internationale, September 14, 2003, WWW . onphi. net/corpus/22/soutenance-de-nanterre.

73 ONPhI, "Statuts historiques de l'ONPhI" (Paris, le 21 janvier 2003), Organisation Non-Philosophique Internationale, January 15, 2006, WwW.onphi.net/ corpus/39/statuts-historiques-de-lonphi. The document is signed by Ray Brassier, Gilles Grelet and François Laruelle.

74 Gilles Grelet, "Combattre sur deux fronts,"

Organisation Non-Philosophique Internationale, April 8, 2003, WWW. onphi.net/corpus/4/combattre-sur-deux-fronts\#. above, Ray Brassier, ${ }^{75}$ and it opened a growing community of young international researchers, such as Jason Barker, Sun-Baek Jeong, Jeong Ae Kang, and others.

But, of course, Laruelle was called to communicate inside the ONPhI, and, as he was challenged to, he had to answer Grelet's militant position. A few months after the beginning of the ONPhI, Laruelle's attitude was then to theorize (on) the occasion of Non-Religion, the traditional move of Parricide (at least known in theory since Freud), and to distinguish (especially in order to protect members who were not concerned with radicality) Grelet's stance of theorism from his role inside the organization. What mattered to Laruelle was to question the resentment involved in the introduction of (non-)religion into non-philosophy and to avoid the use of retaliation by calling, among nonphilosophers, for a non-philosophical Ethics of discussion. ${ }^{76}$ Respect and even admiration were profoundly present, but the posture was rather lukewarm as compared to Grelet's claim that the Theorist should be "a moral atomic bomb."77

\footnotetext{
75 Together with Brassier, in 2005 Grelet and Laruelle started a new series of publications, Nous, les sansphilosophie [We, the ones-without-Philosophy], meant to welcome anti-philosophical, non-philosophical and extraphilosophical essays, whose content and language were not destined to fit the academic taste.

76 François Laruelle, "Parricide. Ou comment Saint-Gilles à l'Épée rectifie la non-philosophie," Organisation NonPhilosophique Internationale, october 3, 2003, www.onphi. net/corpus/24/parricide--ou-comment-saint-gilles-a-lepeerectifie-la-non-philosophie.

77 Gilles Grelet, "Fils de l'homme, frère du peuple:
} 
Laruelle was compelled to answer at a level higher than ONPhI's. At a theoretical level, he had to assume the position of answering Grelet's theorist matrix, as Grelet had put it in axioms in his doctoral dissertation and in his book Déclarer la gnose, and as he had turned it into activism on an international scale with the ONPhI. But given the role that Grelet has taken among non-philosophers, and given their complicit relationship and the influence that they had on each other, it was no longer a matter of a simple footnote. The answer that Laruelle had to give to Grelet's proposal of Non-Religion would be a complete book: Struggle and Utopia at the End Times of Philosophy, which is, for more than half of it, a precise answer to the sharpness of saint Gilles' sword and a specific attempt to reclaim and to re-found 0 NPhI's theoretical basis. ${ }^{78}$

voilà le théoriste," Organisation Non-Philosophique Internationale, November 2, 2004, WwW.onphi.net/ corpus/30/fils-de-lhomme-frere-du-peuple--voila-letheoriste; English edition: Gilles Grelet, "Son of Man, Brother of the People: Behold the Theorist," trans. by Ray Brassier, Organisation Non-Philosophique Internationale, November 2, 2004, wWw.onphi.net/ corpus/29/son-of-man-brother-of-the-people-behold-thetheorist.

78 "Saint Gilles" (related to Marx and Engels's Holy Family) and "Tintin in the Land of Culture" (Grelet, Déclarer la gnose, 4) are two nicknames, or terms of endearment (hypocorisms), given to Grelet by Laruelle which illustrate pretty well the extent and the affective spectrum of their relationship, at least from Laruelle's point of view - to carry the complete investigation, hypocorisms given to Laruelle by Grelet are missing, of
With this in mind, we can assert that this book, as a response to the parricide, which "in reality [...] constitutes the father, or else enjoys giving itself a father,"79 was for Laruelle a struggle with the Angel as his own production, as his own progeny, as himself perhaps - Rebellion being taken as an object "putting non-philosophy to the test."80 Taken in detail, all of Grelet's Gnosis appears, in Laruelle's assessment, to be about "deficient analyses or limits of philosophy," which involve preferring (Non-)Religion to (Non-)Philosophy, because this Gnosis has "already begun with a religious reduction of philosophy": "Emasculating philosophy as imaginary makes the task easier... ."81 At a technical level, though Grelet states that "Religion is more world-thought than Philosophy," Laruelle considers that "it does not provide either the adequate vocabulary nor the critical technique that philosophy provides and which are necessary in order to be able to speak of non-religion in the name of the Real"82; and because of that, it risks "be[ing] confronted with [Philosophy's] return

course...

79 François Laruelle, Lutte et utopie à la fin des temps philosophiques (Paris: Kimé, 2006), 153; Laruelle, Struggle and Utopia, 183-4.

${ }^{80}$ Laruelle, Lutte et utopie, 159; Laruelle, Struggle and Utopia, 191.

81 Laruelle, Lutte et utopie, 148, 149; Laruelle, Struggle and Utopia, 178, 179.

82 Grelet cited in Laruelle, Lutte et utopie, 156;

Laruelle, Struggle and Utopia, 187. 
in the form of the sufficiency of a theological or philosophical 'absolute.'"83 But looked at the level of an intersubjective behavior, facing the emergence of a dissidence, Laruelle's process is once again to give a place and an identity to the autonomous insider, carrying him back to the outer margins.

This identity would be a philosophical one: Platonism, "[t]he instance of the Angel is a repeat of Platonic mania"84; an identity which could even be recognized in Grelet's writing style, within the characteristics of which Laruelle finds "some linguistic fetishism and a secret idealism of the all-language or of language as absolute."85 And the place would be the one of a leftist deviation of nonphilosophy, leading to the conclusion that "the Rebel is in-hatred of the World" but, not being indifferent enough to the World's Sufficiency, "he thus hates the World with the means of the world," 86 i.e., a place which would be now coordinated in the perspective of Laruelle's nonphilosophy.

Though explicitly composed as a friendly fencing match, even with a sort of paternal affection and a professorial care, Laruelle

83 Laruelle, Lutte et utopie, 149; Laruelle, Struggle and Utopia, 179.

84 Laruelle, Lutte et utopie, 181; Laruelle, Struggle and Utopia, 220.

85 Laruelle, Lutte et utopie, 155; Laruelle, Struggle and Utopia, 186.

86 Laruelle, Lutte et utopie, 151; Laruelle, Struggle and Utopia, 181. clearly declares that "all the critiques of non-religious gnosis that non-philosophy bears here only touch on the hasty intervention into non-philosophy by non-religious gnosis (its aspect of leftist deviation), but in no way whatsoever bears upon a possible usage of this thematic" 87 ; though he had taken very seriously Grelet's work and his rigorous and demanding theses and, as a response, ended up writing his most contextual book ever by answering local objections or challenges to social organization (what can be seen as a rare homage, even a kind of tribute to his improbable gifted pupil), the message to be heard and to be understood was first and foremost the following: "several 'non-philosophies' may not exist."88 What would be confirmed in practice (and congruously with events in the World) by changing the functioning of the ONPhI and reformulating its status and bylaws in August $2006^{89}$ (after dissolving the former version in January of the same year) was an important strategic move, given the work that Grelet had done by being at the forefront of the initial organization.

\footnotetext{
87 Laruelle, Lutte et utopie, 158; Laruelle, Struggle and Utopia, 190 .

88 Laruelle, Lutte et utopie, 152; Laruelle, Struggle and Utopia, 183. "May not," "cannot"... depending on the translation we choose; but the meaning remains "won not." 89 See "Statuts de l'Organisation," Organisation NonPhilosophique Internationale, 2006, WWW.onphi.net/ statut? lg=fr.
} 
We can consider that the 2002 ONPhI's bylaws were Laruelle's and Grelet's jointly written and co-authored text. ${ }^{90}$ By reforming the ONPhI, Laruelle was endorsing a symbolical, but official, split. But he was also giving a final and decisively clear non-philosophical definition of Heresy, and even more so a definition of non-philosophy accorded to Heresy: "Non-Philosophy is heretical in Philosophy, but it is orthodox inside Heresy."91 The move was to give a place, but a minor one, to the Angel and to the Rebel in the matrix of non-philosophy. But this placing was no longer expressed in terms of Democracy. Laruelle could assert that Rebellion "does not constitute an œuvre, or it is the Rebel in person that is precisely this œuvre" ${ }^{\prime 92}$; but the angelic rebel that Grelet was has made an œuvre as such within non-philosophy, as an operation of metamorphosis which was his deep effect in Laruelle's work: he has brought nonphilosophy to cast off the political scale of its language and to adopt a religious terminology to define its identity, i.e., a deep effect in theory which corresponds to a new metaphori-

\footnotetext{
90 Although the writing in detail was likely led by Gilles Grelet with Ray Brassier, before offering Laruelle to chair the organization.

91 François Laruelle, "Discipline, tranchant, rigueur, leur conversion non-philosophique," Organisation NonPhilosophique Internationale, 2006, wWw.onphi.net/ letters/8/discipline-tranchant-rigueur - leur-conversionnon-philosophique.

92 Laruelle, Lutte et utopie, 170; Laruelle, Struggle and Utopia, 206.
}

cal leap. ${ }^{93}$ In several ways, Grelet has been the seed for the emergence of Messianism as the non-philosophical model of a democratic future, and a giant step for the conceptual development that Laruelle has accomplished toward a non-philosophical Mystique, a Mystique accorded to his own rigor - at least better accorded than Valdinoci's black Mystique was.

This liberal turn of the ONPhI, on the contrary, did not lead Grelet to adopt a low profile, but, instead, made him more elusive both in theory and in the World. Maybe this was in complicit agreement with Laruelle's interpretation of the Rebel in person as being precisely Rebellion's only œuvre, and in this goal lay the desire to use the means of the World. or maybe this confirmed the course of his path as being - rather than to achieve unanimity inside an activist organization of academics, to posit a method that would be able to turn subjects' worldly discourses into Angel practices of poignant solitude. Grelet progressively left behind his professional ties, his friendships in French activist cinema ${ }^{94}$ and also his connec-

93 Let us be clear here: the jump is real, but it is a jump from a former metaphor to a new one inside the theoretical matrix of description.

94 Gilles Grelet was close to Dojo cinéma, a group of avant-garde directors of documentary films (see Aksayam, \#TRANSISTOR), which filmed two important video documents that should really be translated and subtitled. The first one is a filmed session at the International college of Philosophy (CIPh), where Grelet led a seminar, and which is of preliminary interest on the matter of how Theorism enforces the effort to raise a new kind of subject. See 
tion with the immediate becoming of the ONPhI, and proceeded out to sea, on a sailing boat, which he outfitted as an integral part of his theoretical apparatus and which he significantly baptized Théorème. He would carry on his break toward saintliness. In 2007, once more he made use of his discipline (of) division, and stated on a scathing, small print run poster which announced the publication of his Proletarian Gnosis"95: "THERE ARE THE LIVING, THE DEAD, AND THOSE WHO GO TO THE SEA," signed as "He for Whom the World Is a Brothel where Practice Is the Whore and Philosophy Is the Great Madam."96

It is hard to assess how far the present paper has invested in committing a crime by telling backstage anecdotes of the History of Non-Philosophy. More than revealing any kind

Un séminaire de théorie de Dojo cinéma, Daily Motion, wWw.dailymotion.com/video/x3mw7a. The second one, Une Bonne Manière de commencer, is an amazing experimental short film - amazing both because of its cinematographic and incredibly innovative form as a documentary and its theoretical content - that was produced by Gilles Grelet and Hugues Choplin, the first presenting a theoretical Kōan and the latter making theoretical live comments from another place while Grelet is explaining his pitch. See Une Bonne Manière de commencer, Daily Motion, WwW. dailymotion.com/video/xzfsg.

95 See Gilles Grelet, "Tract(atus) 23: La théorie est attente," en Aksayam, \#TRANSISTOR; Gilles Grelet, "Proletarian Gnosis," trans. by Anthony Paul Smith, Angelaki: Journal of the Theoretical Humanities, Vol. 19, No. 2 (April 2014), 93-8.

96 Surprisingly, this poster happened to be widely distributed and was translated in numerous languages, especially inside the network of European Art Galleries. [The poster and all of its translations are reproduced in this issue of Identities, see infra, 108-11. of supplementary truths, it belongs in the last instance to the increasing amount of fictions that are currently accumulating around non-philosophy and are forming puddles of statements like mirrors, curiously shimmering with iridescent facts and dark irradiant coruscations of Thought. This is fiction and is a hierarchically authoritarian one, at least because it takes place (how not to take heed of this from now on, when asking about giving an identity?) with regard to Laruelle's work, and places these two figures of dissidence that we have presented here only with regard to his non-standard thought rather than doing the opposite. But we all know, at least since Einstein and Poincaré, that giving coordinates to any object and to any of its movement of acceleration depends on the choice we make of a reference frame. Choosing the one's unilateral causality, determination in the last instance, force (of) thought or non-thetic-transcending as universal constants of appreciation to be assessed and to be identified from the perspective of a unified theory, every kind of theoretical proposition might have some predictable influence on our descriptions, on the power that we recognize in non-(non-Philosophical) thoughts, or on the understanding of the semantics and hermeneutics which they rely on - at a minimum, it might have curious anamorphic effects, even if it preserves their structural proportions (Gestalt). 
We also know that depending on our cultural background, but even more so on our entry point, when penetrating non-philosophy (whether it be a random point, or a Philosophy II point or a Philosophy IV point or a secondary literature point, etc.), there will be plenty of partial, limp, crippled, mutant, semi-blind, trivial, unrigorous, waiting-for-answers nonphilosophies, or at least ones in the process of identifying themselves, and waiting (suffering?) for the manifestation of their being determined-democratic or quantum-chaotic, unilaterally-inventive or heretical-orthodox... whether or not it would be the case. Perhaps, indirectly, this paper might somehow help. (But maybe we have to wish that it makes all of this even more difficult.)

Regarding their democratic claims, the two examples of dissidence detailed above and the unilateral functioning, which our analysis began to look at, tend to show that rather than pertaining to Democracy in itself by essence, non-philosophy endeavors to be protective for Democracy, or to guarantee Democracy among the objects and processes that it applies to. But becoming one of these objects or processes implies satisfying very rigorous and very demanding conditions. And these conditions in the end always lead these objects or processes to the same result, i.e., their being neutralized. It is easy when dealing with Philosophy because the tool was built to accomplish this exact purpose with an undeniable and admirable virtuosity. But when confronted with theoretical apparatuses that claim not to fit inside Philosophy's frame, things tend to become more difficult.

In this case, then, the apparatus ought to be first neutralized by Philosophy itself to be suitable for non-philosophical Democracy this is what happens to Religion, which "does not provide either the adequate vocabulary nor the critical technique that philosophy provides" in order to be spoken of "in the name of the Real."97 If not, the apparatus is sent back to an interspace between Philosophy and NonPhilosophy (as we have seen in the case with europanalysis), from whence its articulation within Democracy somehow fails, because there is nothing like non-philosophical Democracy for thoughts that cannot be spoken of "in the name of the Real," but only a residual place, an interworld that looks like the limbos of Rationality. And here stands maybe something more, something deeper.

only the few who have read Grelet's Déclarer la gnose before reading Struggle and Utopia know that indeed Gnosis deploys via a double irrationalist, theosophical and messianic imperative (not to believe in death and play the Angel, as we already said above), and

97 Laruelle, Lutte et utopie, 156; Laruelle, Struggle and Utopia, 187. 
that consequently it involves "the unrestricted dislocation of all that makes life merely possible," "what is called Enthusiasm, the other side of Melancholy: all the greatness of humanity is able to 'concentrate' in it, but in an immediate reciprocation with naked horror."98 Grelet specifies his thought in one of the very last theorems of his book, the penultimate one: "the subjective structure of the Gnostic stems from the alternation of exaltation periods and dejection periods," and this is explicitly "the messianic condition": what it describes is the immediate affect of the one according to Gnosis, the one innerly lived, ever and everywhere, as being divided. ${ }^{99}$ And what this leads him to say is that Love (the metaphysical one, that cuts and unites and cuts as it unites) is, as such, some thought, "it is even Thought par excellence"; and that its propositions, "deeply rooted in Melancholy," can be called pathemes. ${ }^{100}$ Surprisingly, Grelet ends his book on the terrain where serge Valdinoci dwells (but without any reference to him).

Save for referring Melancholy in the last instance to Platonic mania, Laruelle has never confronted Melancholy, or manic depression, not even any other affect or further psychiatric aspects, to conduct his analyses of angelic Rebellion. We already mentioned his reluctance

98 Grelet, Déclarer la gnose, 96.

99 Ibid., 98.

100 Ibid. 102. to any "psychologization" of the Real (even his late tendency to insist on the formal character of the one, rather than on its lived affective character), and also how rare, until recently, his approaches to the body have been, and even more rarer when it comes to lived incarnation. Perhaps, then, we can hypothesize that the nonphilosophical apparatus finds here the limits of the democratic field it provides and presumably finds why it needs at least a previous philosophical reduction of its objects in order to operate. Laruelle's non-philosophical tools might rather be broadly Logos-centered tools, and this could be especially consistent with his own path through Heideggerian hermeneutics and through Derridean deconstruction.

Even if in its hierarchical syntax nonphilosophy resorts to some unknown sort of dispersive empty monotheism, like Artaud's crowned anarchist or Deleuze's betrayer-King Richard III, ${ }^{101}$ to (perhaps?) a monotheism-withouttheos which radicalizes negative theology by implanting Multiplicities into itself, nonphilosophy probably provides the widest and most comprehensive democratic facilitation for rationalities, i.e., for world-discourses or

101 On these, see Antonin Artaud's one of a kind novel Heliogabalus; or, the Crowned Anarchist, trans. by Alexis Lykiard (Chicago: Glitter Books, 2006), and Gilles Deleuze and Claire Parnet, "On the Superiority of Anglo-American Literature," in Dialogues, trans. by Hugh Tomlinson and Barbara Habberjam (London: The Athlone Press, 1987), 45. 
for conceptual matrices. But what about Democracy happening to affects, or, which is kind of scarier, affects happening to Democracy? Is non-philosophy still operating when Thought is not likened to Logos, to Writing, or to Law, but enlarged to non-conceptual or non-conceptualized experiences (such as affects, impressions, motor reflexes, visceral behaviors), to experiences that have not been formerly placed under the mastery of Rationality but yet have to live together, and even have to cohabitate, in the first place as embodied experiences which are not solvable in Philosophy? or can we imagine a non-philosophical matrix which would not rely in the last instance on ideas (but is not it here nothing more than a retaliation of the accusation of Platonism, in the form of a nominalistic Platonism?), but on unconceptualized events happening to a sensitive formless lived matter? Maybe the now long delayed third volume of the trilogy that opened with Future christ, and advertised as Non-Érotisme [Non-Erotism], or the eagerly awaited coming tetralogy on music, could begin to answer such questions.

surely, we are not able to re-enact the distribution of affects that have animated each historical move by which the production processes of non-philosophy have been governed only fictions can do so. We also cannot re-enact Laruelle's own affects or the economy of affects that has led his relationships with fel- low thinkers, be they peers or disciples. We cannot even re-enact what portion of strategy or decision was involved there. Outside theory, precisely as the two-sided man that we suggested he could be, though (but of course) in-one, Laruelle has kept well his friendly relations with his former sidekicks. Nevertheless, during the 2014 international colloquium at Cerisy, ${ }^{102}$ certainly the most important international academic event gathering around him every generation of non-philosophers for a five-day conference session of theoretical work, there were two obvious absentees: Serge valdinoci and Gilles Grelet.

As we have seen, they both have been associated for a while, and with the most dynamic influence, with Laruelle and non-philosophy. From a Humean perspective, in accordance with the three principles of associationism, ${ }^{103}$ the association with Valdinoci was one of contiguity, supported by the spontaneous proximity of two uncompromising pioneers. The association with Grelet was rather one of engendering, supported by the seminal causation of a master on his disciple. So, we would have to ask, who could have been with Laruelle in a similar as-

\footnotetext{
102 "La philosophie non-standard de François Laruelle," du mercredi 3 septembre au mercredi 10 septembre 2014, Centre Culturel International de Cerisy, 2014, WWw.cciccerisy . asso.fr/laruelle14.html.

103 In Hume's psychology, the three principles of associationism are resemblance, contiguity, and cause and effect.
} 
sociation but based on the principle of resemblance?

In the affective confrontations and comparisons of affective influences, i.e., in sharing one's life in an intimate co-determining creativity and exchange of working dynamics; in a supportive emulation that overcomes utmost adversities; but also in the stamina of a longlasting embodied companionship, the winner is always the spouse, i.e., the wife in the last instance. Because the couple, in the depth of their exchange of gazes, provides as a real concrete face "the immediate reciprocation of the naked horror," which Grelet was positing. But it also provides the immediate reciprocation of love facing horror in a conjoined existentialism becoming aware, by sharing lives with one another, of its vulnerability, of its risks and of its value. Although not necessarily in the fulgurant lightning of an aphorism or in the immediate rapture of a gut feeling, this reciprocity of love is constructed as a long-lasting and slow, daily process that measures a fidelity, specifically in light of dealing with infirmity, raising children, and home-building that enables enough serenity to nurture creation. Such a thing - fellowship is probably able to affect only monks confined in the same abbey for a lifetime, or under the fire of warfare. So far, we are not able to tell - and it might have to be a matter of our future readings of their respective writings if Anne-Françoise Schmid happened to elaborate her association with François Laruelle on the basis of the Humean principle of resemblance. But we already know that the jointly written text which they have co-authored is not only a conceptual one: it lasts throughout the closure of the metaphorically numbered periods of non-philosophy, and it provides an intense and fruitful dispersion of affection around them, which is enjoyed by their closest collaborators, as well as the many people who get to know them. And this text, since it is the text of their very lives spent together, is both embodied and ideal, both dual and one. 